\title{
Proteasome vs Thioredoxin reductase competition as possible biological targets in antitumor mixed thiolate- dithiocarbamate gold(III) complexes
}

\author{
Javier Quero, ${ }^{\mathrm{a}, \mathrm{b}}$ Silvia Cabello, ${ }^{\mathrm{a}}$ Teresa Fuertes, ${ }^{\mathrm{a}, \mathrm{b}}$ Inés Mármol, ${ }^{\mathrm{b}}$ Ruben Laplaza, ${ }^{\mathrm{c}}$ Victor Polo, ${ }^{\mathrm{c}} \mathrm{M}$. \\ Concepción Gimeno, ${ }^{a}$ Ma Jesús Rodriguez-Yoldi ${ }^{b,{ }^{*}}$ and Elena Cerrada ${ }^{a}{ }^{,}$ \\ a Departamento de Química Inorgánica, Instituto de Síntesis Química y Catálisis Homogénea- \\ ISQCH, Universidad de Zaragoza-CSIC, 50009 Zaragoza, Spain. \\ bDepartamento de Farmacología y Fisiología. Unidad de Fisiología, Facultad de Veterinaria, Uni- \\ versidad de Zaragoza, 50013, Zaragoza, CIBERobn, IIS Aragón IA2, Spain. \\ cDepartamento de Química Física, Universidad de Zaragoza, 50009 Zaragoza, Spain.
}

KEYWORDS Colon cancer, dithiocarbamate, thiolate, gold(III), proteasome, thioredoxin reductase, Caco-2 cells

Corresponding author e-mail: ecerrada@unizar.es; mjrodyol@unizar.es

Supporting Information

\begin{abstract}
New mixed gold(III) derivatives with dithiocarbamate and thiolate ligands have been synthesized and characterized. They display high anticancer activity against colon cancer cell lines without affecting to differentiated enterocytes, high stability in phosphate buffered saline solution and resistance to gold reduction in presence of reducing agents in the majority of the derivatives. Some of them show interaction with thioredoxin reductase as derived from in vitro analysis and computational studies. However, a competition between this enzyme and proteasome is detected in cells, which is corroborated by the determination of proteasomal chymotrypsin-like activity inhibition. In addition, some of these dithiocarbamate gold(III) derivatives reduce the cell viability and proliferation by intrinsic apoptotic pathway, with changes in mitochondrial membrane potential, cytochrome c release and caspase 3 activation. Consequently, our results show new complexes with proteasome as possible target in colorectal cancer.
\end{abstract}

\section{INTRODUCTION}

Most of the conventional chemotherapeutic drugs are organic compounds; however, metal-containing derivatives offer many advantages over them, which make coordination compounds attractive as well for the development of new medicinal derivatives. $^{1-2}$

Gold in addition of other metals such as ruthenium is one of the most investigated as a possible alternative to platinumbased drugs, with the aim to reduce the drawbacks induced by conventional anticancer therapy. Previous studies have revealed that the co-administration of sodium dithiocarbamate with cisplatin have provided protection against renal, gastrointestinal and bone marrow toxicity, without decreas- ing its antitumor activity. ${ }^{3}$ However the benefits of dithiocarbamate ligands are limited, because they have been related to potential hazards associated when are not coordinated. ${ }^{4}$ With these considerations many dithiocarbamate metallic complexes have been described able to combine the cytotoxic activity of the metal with the chemoprotective character of these ligands. ${ }^{5-15}$ The ability of these molecules to act as bidentate ligands affords high stability to the resulting metallic derivatives due to the so-called chelate effect, preventing from decomposition through loss of the dithiocarbamate ligand. Furthermore, gold(III) is isoelectronic to platinum(II) and both form four-coordinate square planar complexes, giving rise to the possibility of developing analogues to cisplatin. Considering the ability of dithiocarbamates to act as chelating ligands, many examples of gold(III) dithiocarbamate derivatives have been reported more active than cispla$\operatorname{tin}^{10,14,16-18}$ and able to overcome both intrinsic and acquired resistance. $^{18}$

Unlike platinum based derivatives, gold compounds interact with different cellular proteins ${ }^{19}$ instead of having DNA as their main target, which confers them an important advantage in order to overcome the limitations presented by platinum drugs. Gold coordination compounds have previously been described as potent thioredoxin reductase (TrxR) inhibitors, ${ }^{19-20}$ since the gold atom can interact with the selenium atom of the selenocysteine from the C-terminal redox motif. Moreover, previous studies have shown several dithiocarbamate complexes with the ability to inhibit the proteasome activity, ${ }^{14,}{ }^{18,21-23}$ mainly the chymotrypsin-like activity (CT-L activity), since inhibition of CT-L activity has been proved to be the most effective to induce apoptosis and cell cycle arrest in cancerous cells. The ubiquitin/proteasome system (UPS) is a complex molecular machinery which constitutes the main proteolytic pathway in eukaryotic cells and 
previous studies have suggested that cancer cells are more sensitive than normal cells to UPS inhibition..$^{24-26}$ We have previously described that the presence of gold-thiolate units in combination with phosphane molecules lead to highly cytotoxic derivatives, which in the case of phosphanes derived from PTA (1,3,5-triaza-7-phosphaadamantane) includes a balanced relationship between hydrophilicity and lipophilicity. ${ }^{27-33}$ In addition to the aforementioned favourable properties of the coordination of dithiocarbamate ligands to a metallic center, here we demonstrate that combination of both type of ligands, dithiocarbamate and thiolate, in the same complex results in the synthesis of highly cytotoxic gold(III) derivatives against colon cancer cells. Moreover, studies concerning the ability of these new complexes to induce apoptosis or their implication in cell cycle progression and interaction with BSA are included. Furthermore, interaction with thioredoxin reductase and proteasome has been also studied in order to discern the possible target of these complexes on Caco-2 cells.

\section{RESULTS AND DISCUSSION}

2.1. Synthesis and characterization. Treatment of the dithiocarbamate gold(III) derivatives $\left[\mathrm{AuCl}_{2}\left(\mathrm{~S}_{2} \mathrm{CNR}_{2}\right)\right]$ with a freshly prepared thiolate solution, obtained by deprotonation of the corresponding thiol (R'SH) with NaOEt in ethanol, gives rise to dark solutions accompanied by metallic gold precipitation. To avoid such gold decomposition, the use of tin complexes as thiolate and/or dithiolate transfer reagents have been previously proved as an effective route in the preparation of gold(I) and gold(III) compounds under mild conditions ${ }^{34-36}$. Therefore, the reaction of $\left[\mathrm{Sn}\left(\mathrm{SR}^{\prime}\right) \mathrm{Cl}_{2}\right]^{37}$ with $\left[\mathrm{AuCl}_{2}\left(\mathrm{~S}_{2} \mathrm{CNR}_{2}\right)\right]$ affords new thiolate-dithiocarbamate gold(III) derivatives according to scheme 1.

Their ${ }^{1} \mathrm{H}$ NMR spectra display the resonances corresponding to both pyrimidine units and the dithiocarbamate substituents, which are equivalent in solution. In addition, the IR spectra point to a bidentate symmetrical disposition of the dithiocarbamate ligand as deduced from the presence of a unique band in the region due to the $-\mathrm{CSS}$ moiety ${ }^{38-40}$ (see experimental).

This geometry has been corroborated with the crystal structure of $\left[\mathrm{Au}\left(\mathrm{SMe}_{2} \text { pyrim }\right)_{2}\left(\mathrm{~S}_{2} \mathrm{CNMe}_{2}\right)\right]$ (7) and $\left[\mathrm{Au}\left(\mathrm{SMe}_{2} \text { pyrim }\right)_{2}\left(\mathrm{~S}_{2} \mathrm{CNBz}_{2}\right)\right]$ (9) (SMe ${ }_{2}$ pyrim = 4,6-dimethyl2-mercaptopyrimidine) obtained by X-ray diffraction analy-

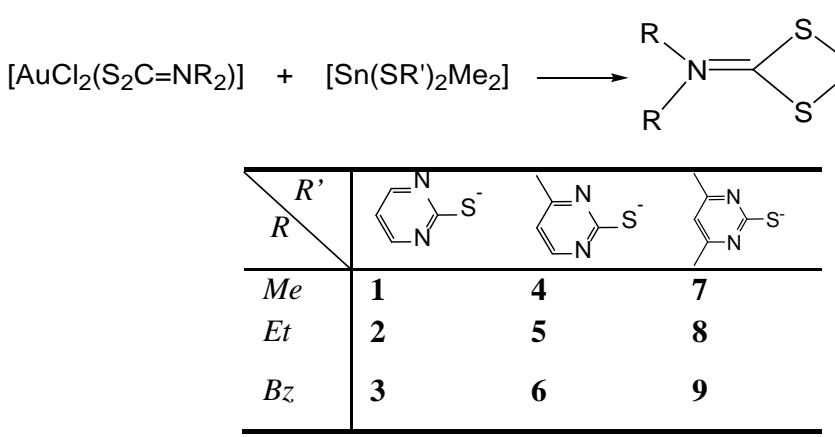

Scheme 1. Synthesis of dithiocarbamate gold(III) derivatives sis.

Most of the X-ray structures of bidentate dithiocarbamate gold(III) derivatives retrieved from CSD Cambridge Data Base 2017 consist on the homoleptic bis-dithiocarbamate complexes or the corresponding dihalogen dithiocarbamate derivatives. Only three examples comprise an additional monodentate dithiocarbamate moiety: $\left[\mathrm{Au}\left(\mathrm{CH}_{2} \mathrm{P}(\mathrm{S}) \mathrm{Ph}_{2}\right)\left(\mathrm{S}_{2} \mathrm{CNEt}_{2}\right)\right],{ }^{41}\left[\mathrm{Au}\left(\mathrm{S}_{2} \mathrm{CNEt}_{2}\right)_{2}(\right.$ damp $\left.)\right]($ damp $=$ $\left.-\mathrm{C}_{6} \mathrm{H}_{4} \mathrm{CH}_{2} \mathrm{NMe}_{2}\right)^{42}$ and $\left[\mathrm{Au}\left(\mathrm{S}_{2} \mathrm{CNR}_{2}\right)_{3}\right]^{43}$ and one with a dithiolate ligand $\left(\left[\mathrm{Au}\left(\mathrm{S}_{2} \mathrm{CNR}_{2}\right)(\mathrm{mnt})\right]\right.$ ( $\mathrm{mnt}=$ malonitriledithiolate)]. ${ }^{44}$ None of them have thiolates as ancillary ligands.

The molecular structures of complexes 7 and 9 are shown in Figure 1 and 2 respectively. Both present a square planar geometry around the gold center, which is bonded to four sulfur donor ligands, to the dithiocarbamate as chelate and to two monodentate thiolate ligands. The Au-S bond distances in complex 7 within the dithiocarbamate ligand are unsymmetrical, with one shorter Au-S bond of 2.3363(13) $\AA$ and one longer of 2.3501(13) $\AA$; whereas the bond lengths to the thiolate ligands are very similar and in the middle of the latter distances, 2.3415(13) Å and 2.3462(13) Å. The geometry of the gold center is square planar and the main distortion arise from the narrow bite angle of the dithiocarbamate ligand, $74.99(5)^{\circ}$, although is worth mentioning that the angle $\mathrm{S}(3)-\mathrm{Au}(1)-\mathrm{S}(4)$ with the two thiolate ligands is also quite narrow, $79.75(5)^{\circ}$, probably to allow the two bulky substituents to be further apart of the $\mathrm{AuS}_{4}$ moiety. In contrast for complex 9 the Au-S bond lengths are longer in the dithiocarbamate, $\mathrm{Au}(1)-\mathrm{S}(1)$ 2.3452(10) $\AA$, Au(1)-S(2) 2.349o(11) $\AA$, probably because of the lower donor capacity of the benzyl substituted dithiocarbamate compared with the methyl one.

The molecules of complex 7 are associated in the crystal through intermolecular short Au...S contacts of $3.589 \AA$, between the gold center of a molecule and one of the sulfur atoms of the dithiocarbamate ligand $\mathrm{S}_{2}$ in a slipped fashion (Figure $\mathrm{S} 1$ ). This interaction is missing in complex 9 probably because the higher steric hindrance of the benzyl groups.

2.1. Solution chemistry. The stability of the complexes was analyzed by UV-visible. They are moderately soluble in organic solvents other than hydrocarbons. Solutions suitable for spectrophotometric analysis were prepared by diluting acetonitrile or dimethylsulfoxide mother solutions of the complexes with $\mathrm{PBS}$ buffer at $\mathrm{pH}=7.4$. The resulting solutions were monitored over $24 \mathrm{~h}$ at $37^{\circ} \mathrm{C}$. The spectra of the complexes display bands (Figure $S_{2}$, supplementary material) in the region 300-400 $\mathrm{nm}$, characteristic of the gold(III) chromophore assigned as LMCT bands. ${ }^{45}$ In complexes 1-5 the transitions remain without any changes in shape or displacement in the absorbance maximum over $24 \mathrm{~h}$, implying a substantial stability of the chromophore under physiological conditions.

Complexes $\left[\mathrm{Au}\left(\mathrm{SMe}_{2} \text { pyrim }\right)_{2}\left(\mathrm{~S}_{2} \mathrm{CNMe}_{2}\right)\right]$ (7) and $\left[\mathrm{Au}\left(\mathrm{SMe}_{2} \text { pyrim) }\right)_{2}\left(\mathrm{~S}_{2} \mathrm{CNEt}_{2}\right)\right]$ (8) (with $\mathrm{SMe}_{2}$ pyrim = 4,6-dimethyl-2mercaptopyrimidine) display a slight progressive decrease in intensity of the characteristic bands without shape modifications. 


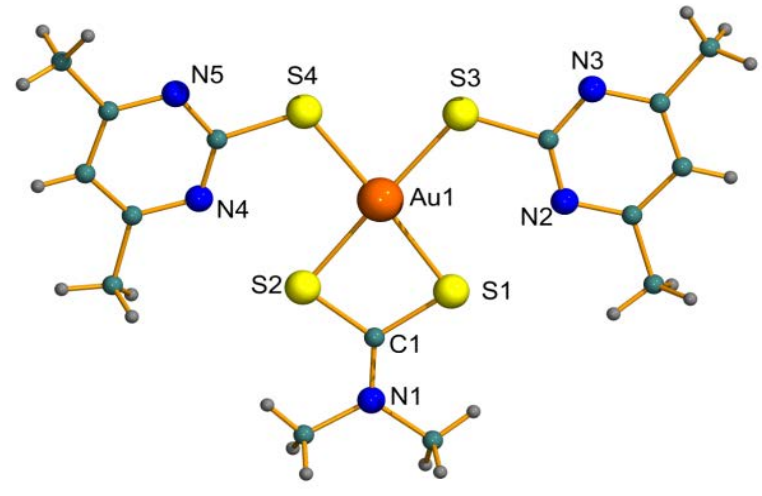

Figure 1. Molecular structure of [ $\left.\mathrm{Au}\left(\mathrm{SMe}_{2} \text { pyrim }\right)_{2}\left(\mathrm{~S}_{2} \mathrm{CNMe}_{2}\right)\right]$ (7). Selected bond lengths $[\AA]$ and angles $\left[{ }^{\circ}\right]$ : $\mathrm{Au}(1)-\mathrm{S}(2)$ 2.3363(13), $\mathrm{Au}(1)-\mathrm{S}(3)$ 2.3417(13), $\mathrm{Au}(1)-\mathrm{S}(4)$ 2.3462(13), $\mathrm{Au}(1)-\mathrm{S}(1) \quad 2.3501(13), \quad \mathrm{S}(1)-\mathrm{C}(1) \quad 1.746(5), \quad \mathrm{S}(2)-\mathrm{C}(1)$ 1.728(5); $\quad \mathrm{S}(2)-\mathrm{Au}(1)-\mathrm{S}(4) \quad$ 101.94(5), $\quad \mathrm{S}(3)-\mathrm{Au}(1)-\mathrm{S}(4)$ 79.75(5), S(2)-Au(1)-S(1) 74.99(5), S(3)-Au(1)-S(1)

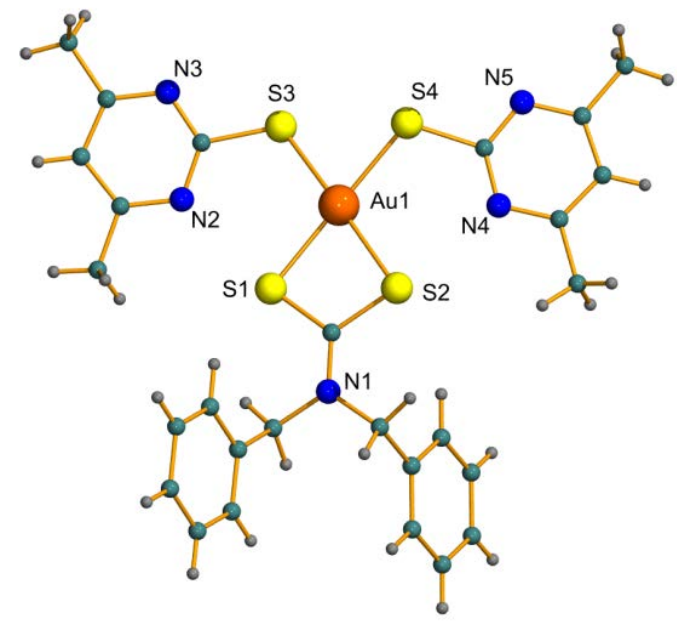

Figure 2. Molecular structure of $\left[\mathrm{Au}\left(\mathrm{SMe}_{2} \text { pyrim }\right)_{2}\left(\mathrm{~S}_{2} \mathrm{CNBz}_{2}\right)\right]$ (9). Selected bond lengths $[\AA]$ and angles $\left[^{\circ}\right]$ : $\mathrm{Au}(1)-\mathrm{S}(4)$ 2.3275(10), $\mathrm{Au}(1)-\mathrm{S}(3) \quad 2.3334(11), \quad \mathrm{Au}(1)-\mathrm{S}(1) \quad 2.3452(10), \quad \mathrm{Au}(1)-\mathrm{S}(2)$ 2.3490(11), S(1)-C(1) 1.733(3), S(3)-C(16) 1.770(3), S(4)-C(22) 1.769(3), S(2)-C(1) 1.736(3); S(4)-Au(1)-S(3) 78.50(4), S(3)-Au(1)S(1) 103.37(3), S(4)-Au(1)-S(2) 103.34(4), S(1)-Au(1)-S(2) 74.99(3).
However, these effects are specially marked in [Au(SMepyrim $\left.)_{2}\left(\mathrm{~S}_{2} \mathrm{CNBz}_{2}\right)\right] \quad$ (6) and $\left[\mathrm{Au}\left(\mathrm{SMe}_{2} \text { pyrim }\right)_{2}\left(\mathrm{~S}_{2} \mathrm{CNBz}_{2}\right)\right](\mathbf{9})$, where the main bands drops to $70 \%$ of its initial intensity, in 9 , probably due to the presence of turbidity during the measurement time, as consequence of their low solubility in the PBS solution. Additionally spectral changes are observed in both cases, that includes a batochromic shift of the LMCT transition band and its disappearance after $24 \mathrm{~h}$, in complex 6. All complexes exhibit stability towards gold(o) reduction, since no broad absorption band at around $550 \mathrm{~nm}$, characteristic of colloidal gold, are detected over $24 \mathrm{~h}$ at $37^{\circ} \mathrm{C}$.

In addition, the stability of some of the new dithiocarbamate derivatives towards biological relevant reducing agents, such as sodium ascorbate (NaAsc), has been evaluated. Figure $\mathrm{S}_{3}$ shows the corresponding UV-vis spectra before and after the addition of NaAsc to a solution of the complex (in molar ratio complex:NaAsc of 1:10) and their evolution over $2 \mathrm{~h}$. Most of the derivatives are rather stable, since their profile remains unchanged, except in the case of $\left[\mathrm{Au}\left(\mathrm{SMe}_{2} \mathrm{Pyrim}_{2}\left(\mathrm{~S}_{2} \mathrm{CNEt}_{2}\right)\right](8)\right.$ where a new band at around $500 \mathrm{~nm}$ grows up along the time, indicating gold colloidal formation, due to the partial reduction of the sample.

2.3. Bovine serum albumin interaction. Bloodstream is largely used to deliver drugs to disease targets in the majority of pharmaceutical treatments. Once in the blood the drug molecule can bind to the different blood constituents, such as plasma proteins. This interaction is electrostatic and hydrophobic and can affect important properties of a drug, such as its absorption and distribution, ${ }^{46}$ which is directly related with drug pharmacokinetics and dosing regimen. Albumin is the most abundant plasma protein. Human serum albumin (HSA) is responsible for the maintenance of blood $\mathrm{pH}$ and osmotic pressure as well as the transport of molecules throughout the body. Bovine serum albumin (BSA) is commonly used as a model protein for HSA owing to their similarity (ca. $76 \%$ ) and its higher availability and stability compared to HSA. BSA possesses three fluorophores: two tryptophane residues (Trp134 and Trp212), with high emission intensity, and tyrosine and phenylalanine residues. The Trp fluorescence is environment sensitive, inasmuch changes in conformation or binding to a substrate, can result in signal quenching. We firstly performed a dialysis experiment to determine the ability of complex $\mathbf{8}$ to bind BSA. A solution of BSA was dialyzed against a solution of the gold derivative in PBS for $24 \mathrm{~h}$. The fluorescence of BSA was measured before and after the dialysis experiment revealing a quenching of the tryptophan luminescence which would be indicative of BSA-gold complex formation (figure $3 \mathrm{~A}$ ). Thereafter, the fluorescence spectra of BSA in the presence of increasing amounts of complexes $\mathbf{1}, \mathbf{3}, \mathbf{4}$, and $\mathbf{8}$ were recorded in the range $310-450 \mathrm{~nm}$ upon excitation at $295 \mathrm{~nm}$. A concentration dependent quenching of the fluorescence is observed, without changing in shape or in the position of the maximum (see figure $3 \mathrm{~B}$ as example).

Fluorescence data were analyzed by the Stern-Volmer equation (see experimental in the supplementary material) and the corresponding plot $\mathrm{F}_{\mathrm{o}} / \mathrm{F}$ vs [complex] ( $\mathrm{F}$ and $\mathrm{F}_{\mathrm{o}}$ are the corresponding intensities in the presence and the absence of the quencher agent) gives a linear plot (Figure $4 \mathrm{~A}$ ) characteristic of the presence of a single mechanism of quenching, static or dynamic. ${ }^{47}$ 

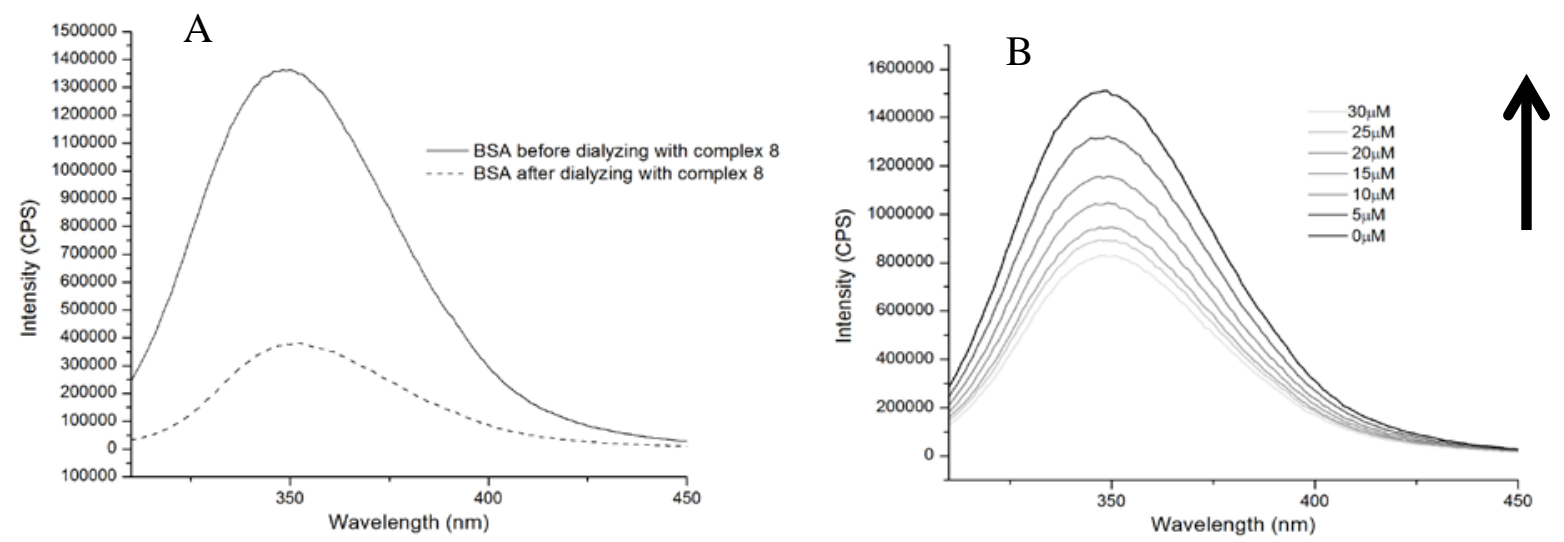

Figure 3. A) BSA dialysis binding study with complex 8. BSA $50 \mu \mathrm{M}$ was dialyzed for $24 \mathrm{~h}$ in the presence of a buffered solution of complex $8(60 \mu \mathrm{M})$. The fluorescence of BSA was measured at $\lambda_{\text {exc }}=295 \mathrm{~nm}$ before and after dialysis. B) Fluorescence quenching spectra of BSA in the presence of various concentration of complex 8 (from o $\mu \mathrm{M}$ to $30 \mu \mathrm{M}$ ) at $\lambda_{\text {exc }}=295 \mathrm{~nm}$. $[\mathrm{BSA}]=50 \mathrm{M}$. The arrow indicates the change in the emission intensity with respect to the increasing amounts of the gold complex

This plot also provides the Stern-Volmer quenching constant $K_{s v}$ (Table 1) and the bimolecular quenching constant $K_{q}\left(K_{q}\right.$ $=K_{S V} / \tau_{o}$, being $\tau_{\mathrm{o}}$ the lifetime of the fluorophore in the absence of the quencher) by using the standard value of around $10^{-8}$ for $\tau_{\mathrm{o}}{ }^{48}$ being all values in the same order. Static quenching implies formation of a complex involving the quencher and the biomolecule, however dynamic quenching is caused by collisions between the protein and the quencher. Both mechanisms of quenching can be distinguished by for example, the study of the bimolecular quenching constant, $k_{q}$.
This constant represents the efficiency of quenching or the accessibility of the fluorophore to the quencher. As dynamic quenching depends on diffusion, a $k_{q}$ value higher than the diffusion-controlled rate constant of the biomolecule in water, $10^{10} \mathrm{M}^{-1} \mathrm{~s}^{-1}$, could indicate some type of binding interaction implying a possible contribution of static quenching. In our case, the values of $k_{q}$ are of the order of $10^{12} \mathrm{M}^{-1} \mathrm{~s}^{-1}$, so binding of the complexes and BSA could be considered.

Absorption spectroscopy is a simple method to explore the structural changes of serum albumin and also used to
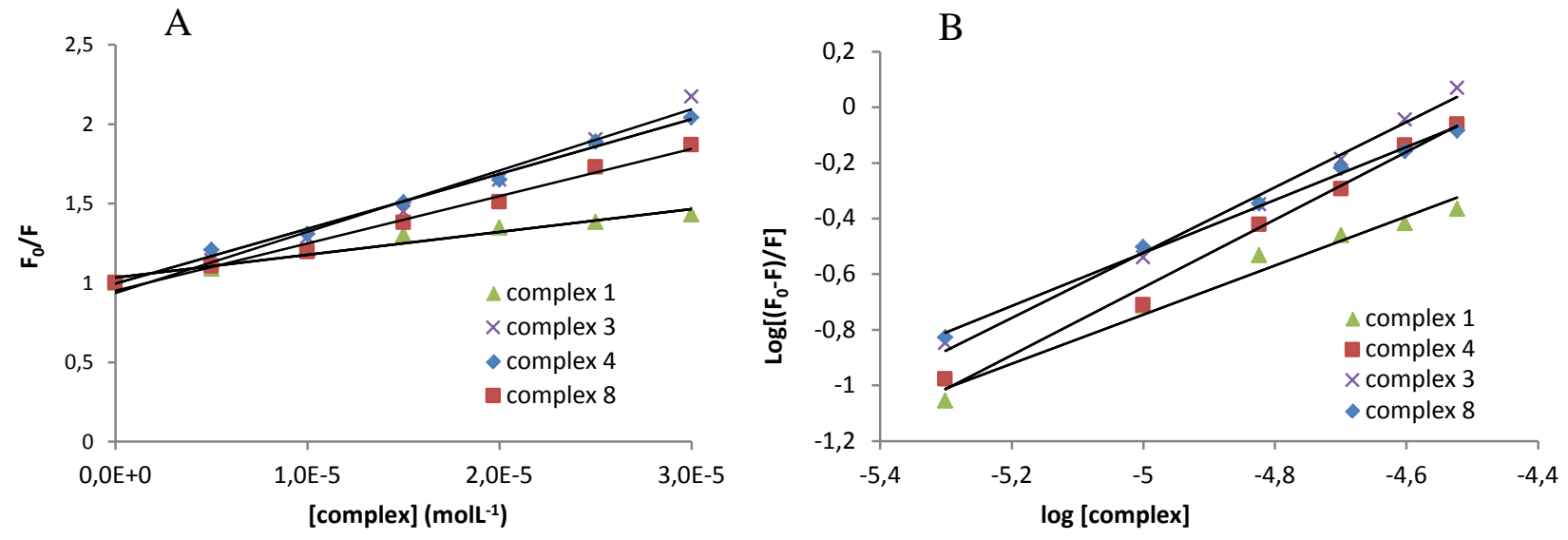

Figure 4. Stern-Volmer plots for the quenching of BSA with increasing amounts of complexes 1, 3, 4 and 8 (complex concentration from $0 \mu \mathrm{M}$ to $30 \mu \mathrm{M})$ at $298 \mathrm{~K}\left(\lambda_{\text {exc }}=295 \mathrm{~nm}\right.$, [BSA] $\left.=50 \mu \mathrm{M}\right)$. (A) Stern-Volmer equation used: $\mathrm{F}_{0} / \mathrm{F}=1+K_{s v}[\mathrm{Q}]$. The slope of the best fit linear trend provides the Stern-Volmer quenching constant $K_{s v}$. (B) Stern-Volmer equation used: $\log \left\{\left(\mathrm{F}_{0}-\mathrm{F}\right) / \mathrm{F}\right\}=\log K_{b}+$ $n \log [\mathrm{Q}]$. The intercept of the best fit linear trend provides the Stern-Volmer quenching constant $K_{b}$. 
discriminate static and dynamic quenching mechanism. UV-vis absorption spectra of BSA were obtained after the addition of increasing amounts of complex 1 (Figure $5 \mathrm{~A}$ ). The UV-vis absorption spectrum of BSA displays a strong band with $\lambda_{\max }$ value of $208 \mathrm{~nm}$, related to changes in the conformation of the peptide backbone and a weak band around $28 \mathrm{o} \mathrm{nm}$ due to the presence of tryptophan and tyrosine residues in the protein. The spectra shown in figure $5 \mathrm{~A}$ indicates a significant increase in the absorbance at $280 \mathrm{~nm}$ by increasing concentration of the complex, which is in accordance with a change in the polarity of the microenvironment around tryptophan and tyrosine residues. ${ }^{49}$ The absorption spectrum of a mixture of BSA and complex 1 in a 1:1 molar ratio, was also measured after dialyzing the solution, in order to eliminate the excess of unreacted complex (Figure ${ }_{5} \mathrm{~B}$ ). As shown in the figure, the peak intensity is increased after the addition of a solution of complex $\mathbf{1}$ that is additionally blue shifted. As dynamic quenching does not affect the absorption of quenching molecule inasmuch as only affects the excited states of the quenching molecule, the changes observed in the spectrum could be indicative of static quenching and

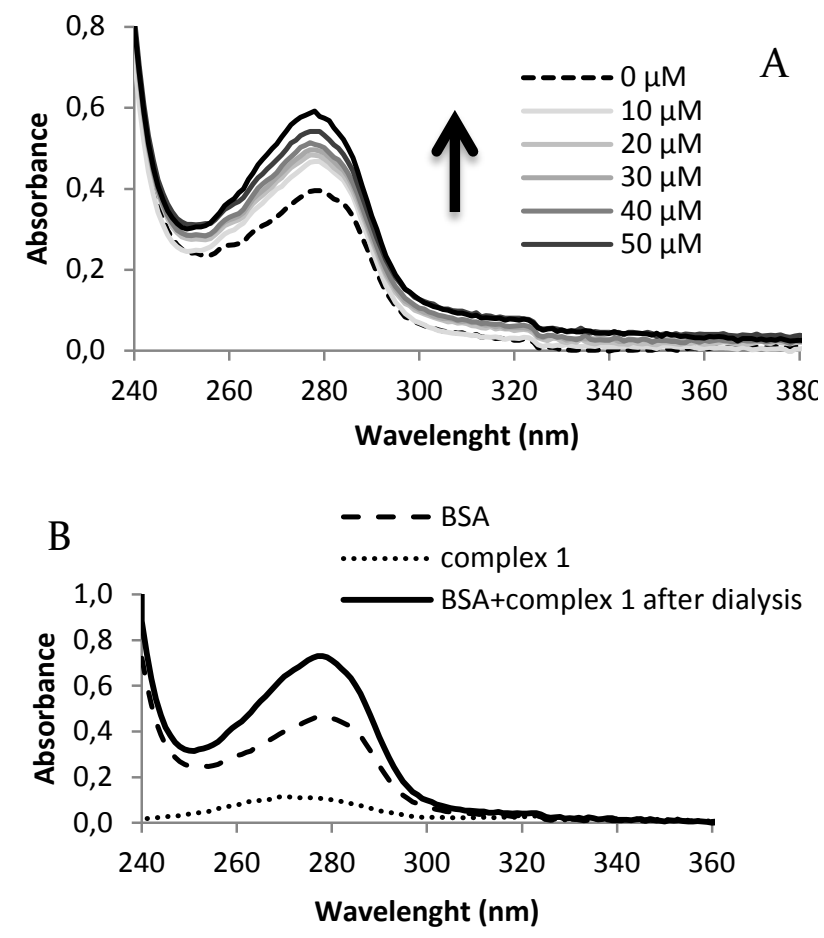

Figure 5. A) Absorption spectra of BSA $(10 \mu \mathrm{M})$ in the presence of increasing amounts of complex 1 (concentration range from $10 \mu \mathrm{M}$ to $60 \mu \mathrm{M}$ ). Equal concentration of the complex was also added to the reference cell (in each measurement) in order to eliminate the absorbance of $\mathbf{1}$ itself. Arrow indicates the increase of the complex concentration. B) UV-Vis absorption spectra of: free BSA $(10 \mu \mathrm{M})$, complex $1(10 \mu \mathrm{M})$ and a mixture of BSA and complex 1 in 1:1 molar ratio after dialysis (solid line).
Table 1. Values of Stern-Volmer quenching constant $\left(K_{s v}\right)$, the number of binding sites and the apparent binding constant $\left(K_{b}\right)$ for the interaction of complexes $1, \mathbf{4 ,} 8$ with BSA.

\begin{tabular}{lccc}
\multicolumn{1}{c}{ Compound } & $\begin{array}{c}\boldsymbol{K}_{\boldsymbol{s v}} \mathbf{x 1 0} \\
\left(\mathbf{M}^{\mathbf{- 1}}\right)\end{array}$ & $\left.\boldsymbol{K}_{\boldsymbol{b}} \mathbf{( M}^{-\mathbf{1}}\right)$ & $\boldsymbol{n}$ \\
\hline$\left[\mathrm{Au}(\mathrm{Spyrim})_{2}\left(\mathrm{~S}_{2} \mathrm{CNMe}_{2}\right)\right](\mathbf{1})$ & 1.44 & $4.6 \times 10^{3}$ & 0.97 \\
{$\left[\mathrm{Au}(\mathrm{Spyrim})_{2}\left(\mathrm{~S}_{2} \mathrm{CNBz}_{2}\right)\right](\mathbf{3})$} & 3.85 & $2.2 \times 10^{5}$ & 1.17 \\
{$\left[\mathrm{Au}(\mathrm{SMepyrim})_{2}\left(\mathrm{~S}_{2} \mathrm{CNMe}_{2}\right)\right](\mathbf{4})$} & 3.45 & $2.71 \times 10^{5}$ & 1.21 \\
{$\left[\mathrm{Au}\left(\mathrm{SMe}_{2} \mathrm{Pyrim}_{2}\left(\mathrm{~S}_{2} \mathrm{CNEt}_{2}\right)\right](\mathbf{8})\right.$} & 2.97 & $1.69 \times 10^{4}$ & 0.95
\end{tabular}

consequently the formation of a complex between BSA and the gold derivative..$^{50}$

Fluorescence intensity data can also afford the binding constant $\left(K_{b}\right)$ and the number of binding sites $(n)$ from the modified Stern-Volmer equation $\left(\log \left\{\left(F_{o}-F\right) / F\right\}=\log K_{b}+n \log \right.$ [gold complex] being $n=$ number of binding sites). (Table 1 and figure $4 \mathrm{~B}$ ). In these complexes the calculated value for $K_{b}$ are in the range $10^{3}-10^{5} \mathrm{M}^{-1}$ next to the previously values observed in other gold(III) complexes..$^{51-52}$ Most of the drugs bind to plasma proteins. This binding should be reversible and the equilibrium between the protein-bound and unbound should be quickly established in order to guarantee drug release to the target. Low to moderate values of binding constant (see Table 1) could facilitate drug transportation by the protein through blood and easy target release.

2.4. Antiproliferative activity. The in vitro cytotoxic effect was evaluated on human colon cancer cell line Caco-2/TC 7 . At first, we studied the effect that the complexes and their dithiocarbamate and thiolate free ligands exerted on the proliferation of colon carcinoma cells after $72 \mathrm{~h}$ exposure to increasing concentrations of the complexes. We obtained promising results since all the tested derivatives showed prominent antiproliferative effect -expressed in terms of $\mathrm{IC}_{50^{-}}$ with values in the micromolar range comparable to those obtained for similar metallodrugs. ${ }^{22-23}$ The free ligands were in general much less effective in decreasing the viability over cancer cells than gold complexes, which confirms that the gold center is necessary to obtain the biological activity (Table 2).

All the complexes display considerably lower $\mathrm{IC}_{50}$ values than that observed with cisplatin and similar values, in most of the cases, or even lower in comparison to auranofin. These values are barely affected by the nature of the substituents in the thiolate unit, however the ethyl group in the dithiocarbamate ligand $\left(\mathrm{S}_{2} \mathrm{CNEt}_{2}\right)$ gives the most active derivatives, with values ranging from 0.56 to $1.0 \mu \mathrm{M}$ and the benzyl residue gives the lowest cytotoxicity. In addition, there is no linear correlation between the lipophilic character of the compounds and their anticancer activity. The increase in the lipophilic character (given in terms of $\log D_{7.4}$, see Table 2) is shown in Figure $\mathrm{S}_{15}$. 
Table 2. $\mathrm{IC}_{50}$ values and distribution coefficients of the thiolate complexes and the free ligands against TC7 colon cancer (undifferentiated) cell lines compared with auranofin and cisplatin.

\begin{tabular}{|c|c|c|}
\hline Compound & $\log D_{7.4}$ & $\mathrm{IC}_{50}(\mu \mathrm{M})^{[\mathrm{a}]}$ \\
\hline$\left[\mathrm{Au}(\text { Spyrim })_{2}\left(\mathrm{~S}_{2} \mathrm{CNMe}_{2}\right)\right](\mathbf{1})$ & 0.62 & $3.43 \pm 2.26$ \\
\hline$\left[\mathrm{Au}(\mathrm{Spyrim})_{2}\left(\mathrm{~S}_{2} \mathrm{CNEt}_{2}\right)\right](2)$ & 0.73 & $0.70 \pm 0.22$ \\
\hline$\left[\mathrm{Au}(\text { Spyrim })_{2}\left(\mathrm{~S}_{2} \mathrm{CNBz}_{2}\right)\right](3)$ & 0.99 & $12.55 \pm 1.71$ \\
\hline$\left[\mathrm{Au}(\mathrm{SMepyrim})_{2}\left(\mathrm{~S}_{2} \mathrm{CNMe}_{2}\right)\right](4)$ & 0.66 & $1.18 \pm 0.57$ \\
\hline$\left[\mathrm{Au}(\mathrm{SMepyrim})_{2}\left(\mathrm{~S}_{2} \mathrm{CNEt}_{2}\right)\right]$ (5) & 1.11 & $0.56 \pm 0.08$ \\
\hline$\left[\mathrm{Au}(\mathrm{SMepyrim})_{2}\left(\mathrm{~S}_{2} \mathrm{CNBz}_{2}\right)\right](\mathbf{6})$ & 1.03 & $2.42 \pm 1.10$ \\
\hline$\left[\mathrm{Au}\left(\mathrm{SMe}_{2} \text { pyrim }\right)_{2}\left(\mathrm{~S}_{2} \mathrm{CNMe}_{2}\right)\right](7)$ & 1.52 & $5.31 \pm 2.88$ \\
\hline$\left[\mathrm{Au}\left(\mathrm{SMe}_{2} \mathrm{pyrim}_{2}\left(\mathrm{~S}_{2} \mathrm{CNEt}_{2}\right)\right](\mathbf{8})\right.$ & 1.51 & $1.00 \pm 0.06$ \\
\hline$\left[\mathrm{Au}\left(\mathrm{SMe}_{2} \text { pyrim }\right)_{2}\left(\mathrm{~S}_{2} \mathrm{CNBz}_{2}\right)\right](\mathbf{9})$ & 0.80 & $5.00 \pm 0.79$ \\
\hline Cisplatin & -0.53 & $45.60 \pm 8.08$ \\
\hline Auranofin & -2.53 & $2.10 \pm 0.40$ \\
\hline SPyrim & & $>50$ \\
\hline SMePyrim & & $>50$ \\
\hline $\mathrm{SMe}_{2}$ Pyrim & & $>50$ \\
\hline $\mathrm{NaS}_{2} \mathrm{CNMe}_{2}$ & & $>50$ \\
\hline $\mathrm{NaS}_{2} \mathrm{CNEt}_{2}$ & & $26.51 \pm 1.80$ \\
\hline $\begin{array}{l}\mathrm{NaS}_{2} \mathrm{CNBz}_{2} \\
\text { [a] Mean } \pm \mathrm{SE} \text { of at least three dete } \\
\text { tions }\end{array}$ & nina- & $14.52 \pm 2.21$ \\
\hline
\end{tabular}

Caco-2 cell line undergoes spontaneous enterocytic-like differentiation when confluency is reached. Therefore, they become polarized cells expressing apical and basolateral surfaces with well-stablished tight junctions. ${ }^{53,54}$ Consequently, it was possible to test the cytotoxic effect of the complexes on differentiated cells (behaving as non-carcinogenic) and compare with the undifferentiated cells viability. Our results suggested that complexes $\mathbf{4}, \mathbf{8}$ and $\mathbf{9}$ were selective towards cancer cells since they displayed higher $\mathrm{IC}_{50}$ values when tested on Caco-2/ $\mathrm{TC}_{7}$ cells over confluence (Table 3). Moreover, it was observed that cytotoxic concentrations of complexes 4,8 and 9 for undifferentiated cells did not compromise the integrity in differentiated cells, since no reduction of their viability were detected after incubation with the gold derivatives at $\mathrm{IC}_{50}$ concentrations (Table S2). This fact suggests that treatment with these complexes would not induce excessive side effects on healthy tissues. The low cytotoxicity of our derivatives in normal cells could be rationalized by the different behaviour of cancerous cells and the different response after incubation with the gold complexes. In fact, tumor cells have both altered and increased metabolic demands. In this regard, thioredoxin reductase is overexpressed in several human cancer cell lines including in colorectal tumors as compared with normal tissues. ${ }^{55-56}$ In addition, cancer cells are more sensitive to oscillations in the ubiquitin proteasome system than normal cells. ${ }^{57}$ Thus, cancer cells require higher rates of protein synthesis and consequently greater requirement for proteasome activity to maintain homeostasis. Some examples have shown that any changes in ubiquitin proteasome activity result in the accumulation of misfolded immunoglobulins, triggering apoptosis, which explain thus the cytotoxic effects of proteasome inhibitors. ${ }^{58}$

Additionally, we have chosen the complex with the lowest $\mathrm{IC}_{50}$ value, $\left[\mathrm{Au}\left(\mathrm{SMe}_{2} \text { pyrim }\right)_{2}\left(\mathrm{~S}_{2} \mathrm{CNEt}_{2}\right)\right](8)$, to be tested to- wards additional cancer cells (MC-7 breast carcinoma) and differentiated cells (liver HepG2) corroborating the selectivity of this type of complex towards undifferentiated or cancerous cells (Tables $\mathrm{S}_{3}$ and $\mathrm{S}_{4}$ supporting information). Thus, complex 8 displayed high cytotoxicity against MC-7 cancer cells with time dependent $\mathrm{IC}_{50}$ values, since lower value was obtained after $72 \mathrm{~h}$ of incubation $(2.25 \mu \mathrm{M}$ at $72 \mathrm{~h}$ vs $3.27 \mu \mathrm{M}$ at $48 \mathrm{~h}$ ) and higher $\mathrm{IC}_{50}$ values were determined after complex 8 incubation with HepG2 cells $(5.96 \mu \mathrm{M}$ at 72 $\mathrm{h} v s 9.80 \mu \mathrm{M}$ at $48 \mathrm{~h}$ ). Both free ligands are less cytotoxic against these cells, reinforcing the importance of the gold center presence.

2.5. Cell death studies. Since the complexes showed the capacity of compromising cell proliferation, we analyzed the type of induced cell death caused by gold(III) dithiocarbamate species. Annexin V/propidium iodide double staining was performed on Caco-2/ $\mathrm{TC}_{7}$ cells and the fluorescence was determined by flow cytometry.

Along the apoptotic process, the cell suffers morphological changes and the phosphatidylserine, an inner membrane phospholipid, is translocated to the outer part of the membrane, where binds to Annexin V (FITC conjugated). Cells undergoing late apoptosis stages and necrosis processes present damaged membranes permeable to PI, whereas cells with intact membranes exclude PI. A prominent increase of Caco-2/ $\mathrm{TC}_{7}$ cells in early stages of apoptosis was detected after $24 \mathrm{~h}$ incubation with complex 8 , whereas treatment with complexes 4 and 9 showed a slight increase in this cell population (Figure 6A). There were not significant changes in late apoptotic cell levels after incubation with either three complexes (Figure 6A). However, higher levels of apoptotic cells, both in early and late stages were observed after 48 h treatment with complexes 4,8 and 9 (Figure 6B).

Apoptosis, a programmed cell death that avoid inflammation and damage to surrounding cells, is ultimately triggered by the activation of executioner caspases $(-3,-6,-7)$. Caspase- 3 activation was studied by flow cytometry after cells incubation with complexes 4,8 and 9 at their $\mathrm{IC}_{50}$ concentration. An increase in active caspase- 3 levels was observed in all the cases after $24 \mathrm{~h}$ incubation (Figure 7 ). This fact could be related to different activation pathways of apoptosis.

There are two different apoptotic pathways, the extrinsic or death receptor pathway and the intrinsic or mitochondrial pathway, which converge in caspase-3 activation. ${ }^{59}$

Table 3. $\mathrm{IC}_{50}$ values determined by MTT assay after incubating differentiated Caco-2/TC7 cells with increasing concentrations $(10,20,30,40$ and $50 \mu \mathrm{M})$ of complexes $\mathbf{4 , 8}$ and $\mathbf{9}$ for $72 \mathrm{~h}$.

\begin{tabular}{lc}
\hline Compound & $\mathrm{IC}_{50}(\mu \mathrm{M})^{[\mathrm{a}]}$ \\
{$\left[\mathrm{Au}(\mathrm{SMepyrim})_{2}\left(\mathrm{~S}_{2} \mathrm{CNMe}_{2}\right)\right](\mathbf{4})$} & $>50$ \\
{$\left[\mathrm{Au}\left(\mathrm{SMe}_{2} \mathrm{pyrim}_{2}\left(\mathrm{~S}_{2} \mathrm{CNEt}_{2}\right)\right](\mathbf{8})\right.$} & $9.86 \pm 0.56$ \\
{$\left[\mathrm{Au}\left(\mathrm{SMe}_{2} \text { pyrim }\right)_{2}\left(\mathrm{~S}_{2} \mathrm{CNBz}_{2}\right)\right](\mathbf{9})$} & $34.70 \pm 0.29$ \\
\hline$[\mathrm{a}] \mathrm{Mean}+\mathrm{SE}$ of at least three determinations
\end{tabular}

\footnotetext{
${ }^{[\mathrm{a}]}$ Mean \pm SE of at least three determinations
} 
Since previous studies on metal complexes suggested mitochondrial dysfunction and intrinsic apoptosis induction, ${ }^{60-61}$ we analyzed two characteristic features of this pathway: mitochondrial depolarization and cytochrome $c$ release.

Throughout the intrinsic apoptotic process, the mitochondrion undergoes the redistribution of ions across the membrane, which alters the concentration gradient of protons that maintains the mitochondrial membrane potential (MMP). The MMP reduction induces matrix condensation, crystal unfolding and cytochrome $c$ redistribution towards intermembrane space. ${ }^{62}$ These structural changes on account of mitochondrial depolarization ultimately lead to cytochrome $c$ release. Once in the cytoplasm, cytochrome $c$ binds to Apoptosis Protease-Activating Factor-1 (APAF-1). Then, this complex recruits and binds to caspase- 9 , constituting the apoptosome, which activates the effector caspase- $3 .{ }^{63}$

To confirm whether the complexes would compromise the mitochondrial membrane potential (MMP), we used the cationic probe $\operatorname{DilCI}(5)$ (1,1',3,3,3'-hexamethylindodicarbocyanine iodide) and performed flow cytometry in order to detect the decrease of fluorescence in cells with depolarized mitochondria in comparison with unaltered MMP cells. As expected, complexes $\mathbf{4}, \mathbf{8}$ and $\mathbf{9}$ decreased MMP in Caco$2 / \mathrm{TC}_{7}$ cells after $48 \mathrm{~h}$ of incubation (Figure $8 \mathrm{~B}$ ). Moreover, complex $\mathbf{8}$ induced mitochondrial depolarization along the

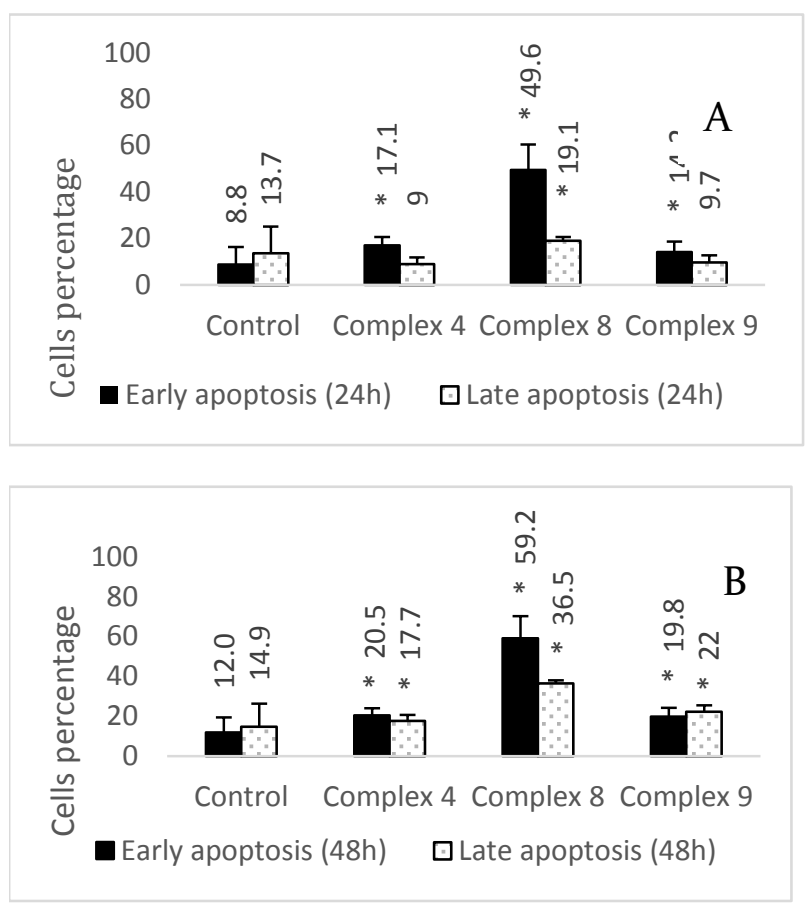

Figure 6. Undifferentiated Caco-2/TC7 cells apoptotic-state analysis after $24 \mathrm{~h} \mathrm{(A)}$ and $48 \mathrm{~h}$ (B) incubation with complexes $4(1.18 \mu \mathrm{M}), 8(1 \mu \mathrm{M})$ and $9(5 \mu \mathrm{M})$. A double staining (Annexin V-PI) was performed and fluorescence was determined by flow cytometry. The results are expressed in \% of cells going through early and late apoptosis. * $\mathrm{p}<0.05$ compared to control.

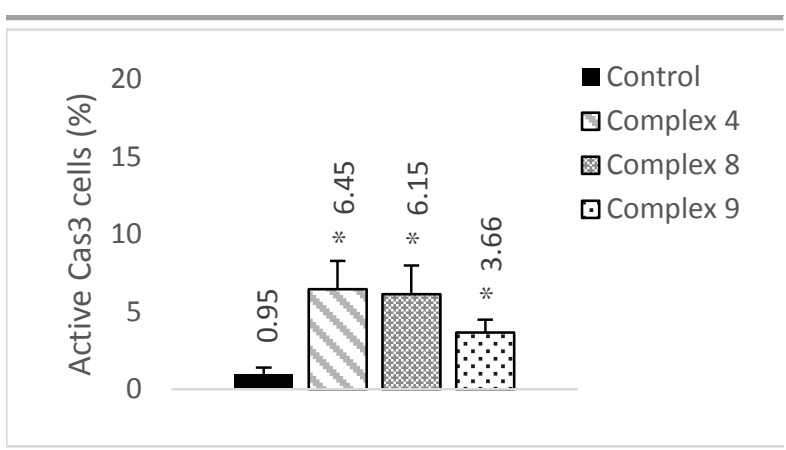

Figure 7. Evaluation of caspase-3 activation by flow cytometry in Caco-2/TC7 cells after 24 h treatment with complexes 4 $(1.18 \mu \mathrm{M}), 8(1 \mu \mathrm{M})$ and $9(5 \mu \mathrm{M})$. Fluorescence of antiCaspase 3 antibody in cells was determined by flow cytometry. The results are expressed in terms of \% of cells with caspase 3 activated. ${ }^{*} \mathrm{p}<0.05$ compared to control

first $24 \mathrm{~h}$ after incubation, unlike complexes 4 and 9 (Figure $8 \mathrm{~A})$. This is well-correlated with our previous results shown in Figure 6, where $\left[\mathrm{Au}\left(\mathrm{SMe}_{2} \mathrm{pyrim}_{2}\left(\mathrm{~S}_{2} \mathrm{CNEt}_{2}\right)\right](8)\right.$ proved to induce apoptosis much faster than $\left[\mathrm{Au}(\mathrm{SMepyrim})_{2}\left(\mathrm{~S}_{2} \mathrm{CNMe}_{2}\right)\right]$ (4) or $\left[\mathrm{Au}\left(\mathrm{SMe}_{2} \text { pyrim }\right)_{2}\left(\mathrm{~S}_{2} \mathrm{CNBz}_{2}\right)\right](9)$ and with the higher lipophilic character of complex 8 in comparison with those of 4 and 9.

Then, we quantified cytochrome $c$ release to cytoplasm by flow cytometry in treated and untreated cells. As expected, after 24 h only cells treated with complex $\mathbf{8}$ showed a significant decrease in mitochondrial cytochrome $c$ levels (Figure. 9), which is in accordance with the results described for mitochondrial depolarization, being complex $\mathbf{8}$ the fastest in its induction and consequently release of cytochrome $c$ to cytoplasm. Based on these results, we conclude that the complexes could induce intrinsic apoptosis in these cancer cells, despite the fact that at $24 \mathrm{~h}$ incubation time only complex 8 produces apoptosis in this way.

2.6. Studies of therapeutic targets: Although there are some examples of gold(III) based metalodrugs ${ }^{64}$ that have shown evidence for a direct DNA damage, for most other cases interaction with DNA appears to be modest or even inexistent and consequently should not be considered as the primary biological target. In our case, we have monitored the influence of complex 1 on pIRES2-EGFP (5308 pb) plasmid DNA, following incubation at $37^{\circ} \mathrm{C}$, by agarose gel electrophoresis, and compared to cisplatin (Figure S16, Supporting

Information). After treatment with increasing amounts of the complex, the mobility of the plasmid was not affected unlike with the observed in cisplatin. Additionally, studies of this complex with calf thymus DNA by vis-UV absorption titration did not provide any changes in the Soret band (data not shown). These results should indicate the absence of an interaction with DNA double helix.

As stated in the introduction, one of the most studied proteins as a possible biological target in gold derivatives is the selenoenzyme thioredoxin reductase (TrxR), involved in the 
regulation of the intracellular state and mitochondrial function. In addition, proteasome has emerged as a new target in cancer therapy, ${ }^{26},{ }_{5}$ since proteasome inhibitors exert the ability to inhibit the growth of cancer cells altering the balance on intracellular proteins. Moreover, several examples of dithiocarbamate gold(III) derivatives have been previously described as potent proteasome inhibitors. ${ }^{10,14,18,22-23}$

Consequently, inhibition of both, the enzyme thioredoxin reductase and the ubiquitin-proteasome system has been evaluated in complexes $\mathbf{4}, \mathbf{8}$ and $\mathbf{9}$ as selected derivatives.

2.7. Interaction with thioredoxin reductase. Thioredoxin system is one of the most important antioxidant systems in mammalian cells and it is constituted by thioredoxin (Trx), the enzyme thioredoxin reductase (TrxR) and NADPH. Although the principal function of thioredoxin system is controlling the intracellular redox homeostasis and repairing oxidative damage, it is as well implicated in cell growth and apoptosis control ${ }^{66}$. Thioredoxin reductase comprises a flexible C-terminal extension with a cysteine/selenocysteine redox center, ${ }^{67}$ able to interact with different substrates and inhibitors, such as gold compounds. ${ }^{68-69}$ In addition, thioredoxin reductase is overexpressed in several human cancer cells compared to normal tissues. ${ }^{55}$ Consequently, some authors regard to this enzyme as a novel target for cancer therapy. ${ }^{70-71}$ Different examples of dithiocarbamate gold complexes have been described as TrxR inhibitors in the literature. ${ }^{72-74}$

Computational studies were performed in order to assess the possible interaction mechanisms between complexes $4,7,8$ and 9 and TrxRı. As the selenocysteine (Sec) amino acid is
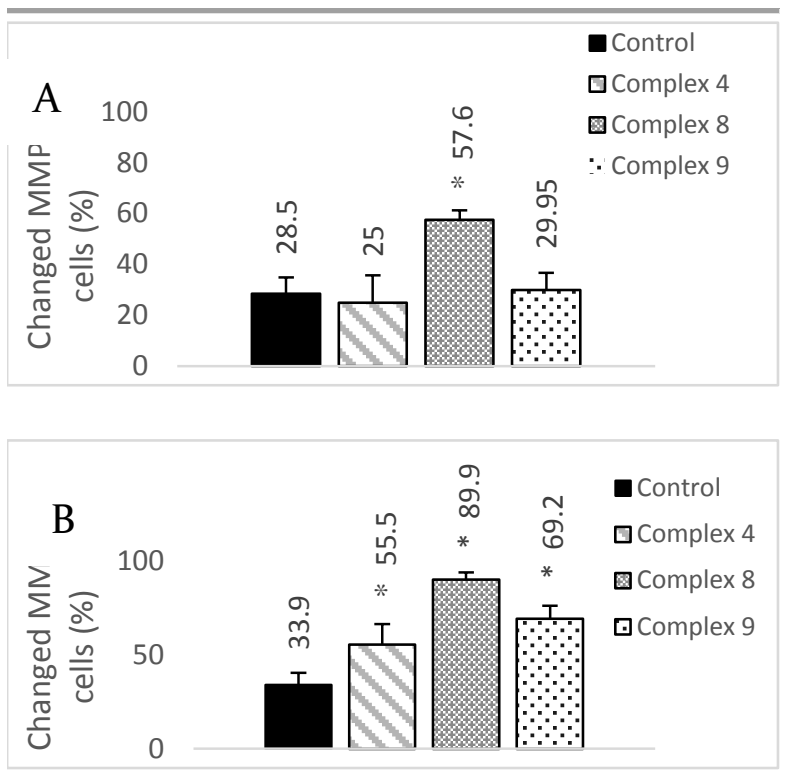

Figure 8. Quantification by flow cytometry of number of cells with mitochondrial depolarization. Colorectal cancer Caco-2/TC7 cells were treated with $4(1.18 \mu \mathrm{M}), 8(1 \mu \mathrm{M})$ and $9(5 \mu \mathrm{M})$ for $24 \mathrm{~h}(\mathrm{~A})$ and $48 \mathrm{~h}(\mathrm{~B})$. Cells were stained with a cationic probe DilCI(5) and fluorescence was determined by flow cytometry. The results are expressed in terms of $\%$ of cells with changed MMP. ${ }^{*} \mathrm{p}<0.05$ compared to control

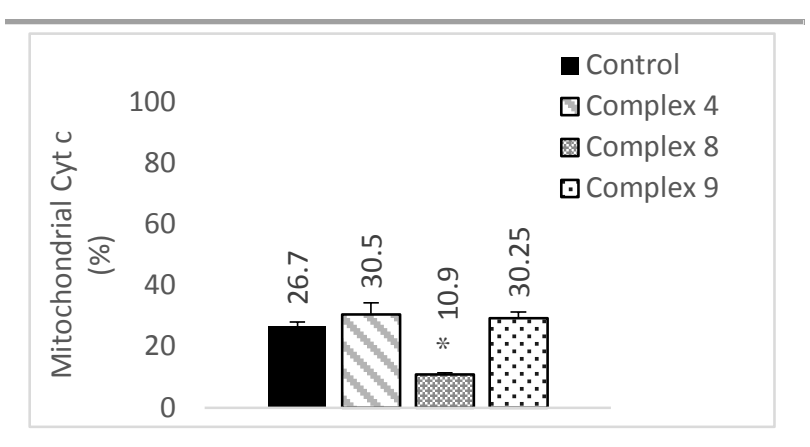

Figure 9. Flow cytometry quantification in terms of \% of mitochondrial cytochrome c in Caco-2/TC7 cells after $24 \mathrm{~h}$ treatment with complexes $4(1.18 \mu \mathrm{M}) \mathbf{8}(1 \mu \mathrm{M})$ and $9(5 \mu \mathrm{M})$. Fluorescence from anti-cytochrome $c$ antibody was determined by flow cytometry. ${ }^{*} \mathrm{p}<0.05$ compared to control

important for high catalytic efficiency and the human TrxR1 structure presents a mutation (Sec-> Cys), ${ }^{75-76}$ the analogous homodimer of rat TrxR1 (subunits A and B) has been selected for the docking studies. As both mammalian proteins (rat and human) present very similar overall folding and sequence, the rat TrxR crystal structure has been selected as target of the docking studies due to the importance of a good description of the active site. Significant differences in the binding mode of complex 9 with respect to 4,7 and 8 , have been found, in correlation with the experimental inhibitory activities. The binding region was located in the surroundings of the selenocysteine residue of subunit $\mathrm{B}$. The volume of the substituted dithiocarbamate moiety appears to be highly relevant, as nonpolar substituents tend to occupy a hydrophobic pocket of reduced size in the proximity of Ala26 A and Ile347 B (Figure S17, supplementary material and Figure 10 as a representative example). The resulting poses favour a highly maintained pair of hydrogen bonds with Ser404 $\mathrm{B}$ and Cys497 B, one to each pyrimidine ring. This hydrophobic pocket is unable to hold larger groups, as seen in complex 9, which is therefore forced to a different pose that lacks the hydrogen bond pair. The nearby presence of subunit $A$ is shown to be secondary in the disposition of the compounds.

In order to analyze the kinetics and thermodynamics of the sulfur-selenium ligand exchange of the $\mathrm{Au}(\mathrm{III})$ complex, a $\sigma$ bond metathesis reaction mechanism has been investigated using quantum-mechanical calculations on a model system at the DFT level using a continuous solvent approach. The calculated free energetic profile for this reaction is shown in Figure S18. A concerted transition structure TSA/B is found for this reaction presenting an energetic barrier of 18.6 $\mathrm{kcal} / \mathrm{mol}$. Interestingly, the geometry of the transition state favors the perpendicular approach of the selenol group to the planar complex, which is shown to be favored for complexes 4, 7 and 8 in the docking calculations.

This value indicates that this process is feasible at room temperature although it is a slow reaction, according to the transition state theory. As expected for an $\mathrm{Au}(\mathrm{III})$ complex, the obtained Au-Se complex $\mathbf{B}$ is exergonic $(-8.5 \mathrm{kcal} / \mathrm{mol})$ and, therefore, thermodynamically favourable. The reverse 


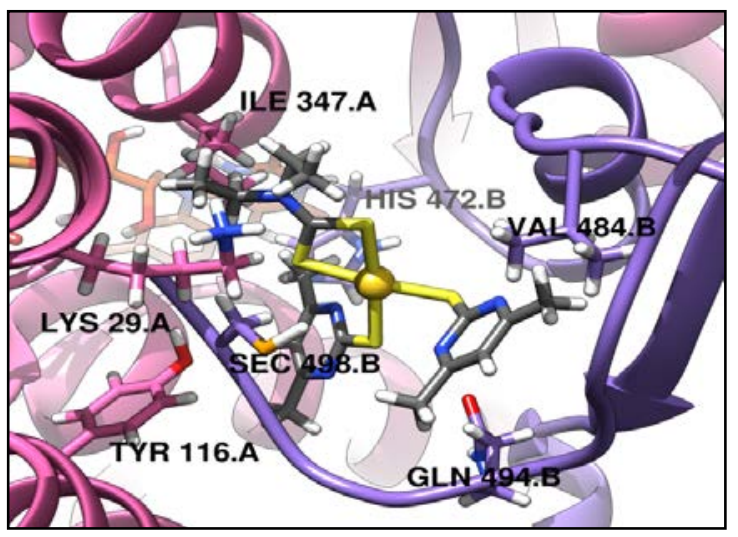

Figure 10. Top ranked interaction models for complex 8 and TrxR1 as representative example. Complex and key residues are shown as sticks, with gold atoms being displayed as golden spheres, while the protein is shown as a pink (subunit A) and a violet (subunit B) ribbon. Nitrogen, sulfur, oxygen, selenium and hydrogen atoms are colored blue, yellow, red, orange and white respectively, while carbon atoms are colored grey or as the subunit they belong to.

reaction, from $\mathbf{B}$ to $\mathbf{A}$, presents an excessively high activation barrier for the experimental conditions $(27.1 \mathrm{kcal} / \mathrm{mol})$. Then, the chemical reaction from $\mathbf{A}$ to $\mathbf{B}$ can be considered as an irreversible process.

The difference in inhibitory activity can thus be linked to both the docking of the drug in the enzyme, which favours certain conformations through non-covalent interactions, and the specific mechanistic features of the Se-Au interaction.

Since computational studies reinforced the possibility of our complexes interacting with TrxR, we determined the thioredoxin reductase activity of human purified TrxR 1 after $30 \mathrm{~min}$ exposure to the gold derivatives. All compounds showed the ability to inhibit purified TrxR1 (Figure S20) triggering a 1.33fold (complex 9), 4-fold (complex 8) and 3.2-fold (complex 4) decrease in the enzyme activity.

Therefore, experimental and computational results are in agreement with the inhibition of the TrxR activity due to the presence of gold-enzyme interactions. Consequently, its inhibition would have an impact on the production of oxidative species, inasmuch the thioredoxin system helps to keep the redox balance inside the cells. Since $\mathrm{H}_{2} \mathrm{O}_{2}$ scavenging is one of the main antioxidant functions for TrxR, ${ }^{77}$ we performed a fluorometric assay (by using 2,7dichlorodihydrofluoescein diacetate, DCFH-DA, which is hydrolyzed by $\mathrm{H}_{2} \mathrm{O}_{2}$ to 2,7-dichlorofluorescein, DCF, inside the cells) to quantify $\mathrm{H}_{2} \mathrm{O}_{2}$ intracellular levels in Caco-2/ $/ \mathrm{TC}_{7}$ cells upon treatment with the $\mathrm{IC}_{50}$ and twice $\mathrm{IC}_{50}$ concentrations of complexes 4,8 and $\mathbf{9}$. There is only a slight increase in the cellular ROS levels after $1 \mathrm{~h}$ of incubation, which remained practically unaltered after $3 \mathrm{~h}$ of incubation (Figure S21).
In order to explain these contradictory results, we determined the interaction with reductase systems in the cells using a colorimetric assay. The experiment, based on the reduction of 5,5'-dithiobis(2-nitrobenzoic) acid (DTNB) to thio-2-nitrobenzoic acid (TNB) allows the determination of the inhibition of thiol reductase activity in Caco-2/ $\mathrm{TC}_{7}$ cell lysates after $24 \mathrm{~h}$ of incubation with the complexes (Figure $11)$.

Figure 11 displays no variation in the thiol reductase activity in cells treated with any of the three complexes, which is in agreement with the results observed in ROS levels. Glutathione reductase and thioredoxin reductase systems, both with cysteine active sites, are able to maintain redox balance inside cells, and their activity depends on the presence of a reduced sulfhydryl group. DTNB is not selective to TrxR, but the presence of any variation in the thiol reductase activity points to the absence of any interaction of our complexes with thiol containing enzymes, among which TrxR is included.

Although all complexes were able to inhibit purified TrxR (Figure S2o), they showed a lack of interaction with its intracellular analogue (Figure 11). It is remarkable that the concentrations of these complexes used to inhibit TrxR is higher than common values for other gold(III) and gold(I) inhibitors. ${ }^{68,78-79}$ Consequently, it is expected that this will not be the likely target in cells, where other possible targets are present. Gold derivatives can interact with different targets inside the cells and therefore some competition can occur from their action. As stated above previous studies have pointed at proteasome as a common target for different dithiocarbamate-based coordination gold compounds. ${ }^{18,22-23}$,

${ }^{80}$, Accordingly, we have analyzed proteasome inhibition by some of these new derivatives.

2.8. Interaction with the proteasome. The ubiquitin/proteasome system (UPS) is a complex molecular machinery which constitute the main proteolytic pathway in eukaryotic cells. The UPS is involved in regulation of basic biological processes such as cell growth, proliferation, cell

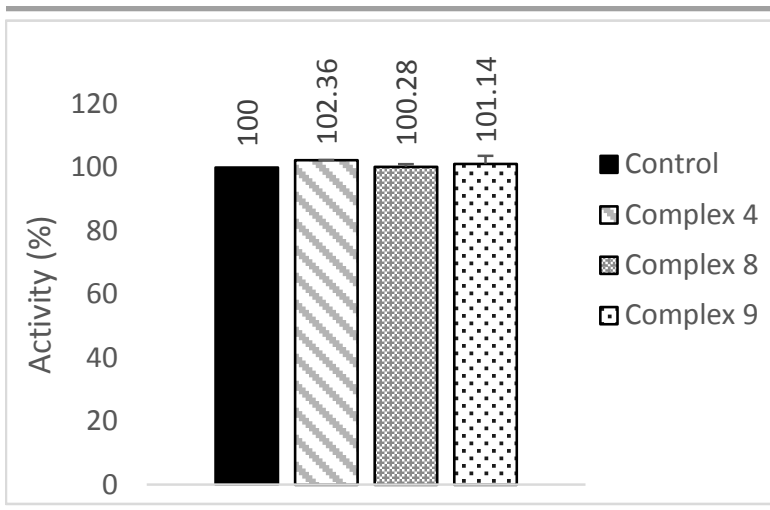

Figure 11. Determination of thiol-reductase activity of Caco2/TC7 lysates after $24 \mathrm{~h}$ incubation with the complexes (complex $4(1.18 \mu \mathrm{M})$, complex $8(1 \mu \mathrm{M})$ and complex $9(5 \mu \mathrm{M}))$. Activity was measured by monitoring DTNB reduction and the results are expressed in terms of \% of activity with respect to control. 
cycle and apoptosis, ${ }^{81}$ and dysregulation of these processes causes malignant transformation. Therefore, several cancer cells have dysfunctional UPS with increased proteasome activity $^{82-83}$ and diverse studies have demonstrated that proteasome inhibition in tumor cells may lead to accumulation of inhibitors of cyclin-dependent kinases, pro-apoptotic and tumor suppressor proteins, hence inducing cell cycle arrest and apoptosis. ${ }^{84}$ To analyze whether the complexes $\left[\mathrm{Au}\left(\mathrm{SMepyrim}_{2}\left(\mathrm{~S}_{2} \mathrm{CNMe}_{2}\right)\right](4),\left[\mathrm{Au}\left(\mathrm{SMe}_{2} \mathrm{pyrim}_{2}\left(\mathrm{~S}_{2} \mathrm{CNEt}_{2}\right)\right]\right.\right.$ (8) and $\left[\mathrm{Au}\left(\mathrm{SMe}_{2} \text { pyrim }\right)_{2}\left(\mathrm{~S}_{2} \mathrm{CNBz}_{2}\right)\right](9)$ were able to interact with the proteasome, hence inhibiting its activity, we performed a fluorometric assay. We used Suc-LLVY-AMC, a fluorogenic substrate of the proteasome $\beta_{5}$ subunit. Therefore, fluorescence levels correspond to the proteasomal chymotrypsin-like activity (CT-L activity). It has been previously demonstrated that inhibition of the CT-like activity is connected with the induction of cancer cells apoptosis programs. ${ }^{85}$ We observed a decrease in Caco-2/ $/ \mathrm{TC}_{7}$ proteasomal CT-L activity after $24 \mathrm{~h}$ treatment with either the three complexes (Figure 12).

On the other hand, the proteasome inhibition by $\mathrm{MG}_{132}$ (Carbobenzoxy-L-leucyl-L-leucyl-L-leucinal) did not show any significative effect on TrxR activity in the cells, which could indicate that this enzyme is not the cellular target of these complexes (data not shown), enhancing the hypothesis that, although a Se-Au interaction exits in vitro, our complexes do not bind TrxR in the cell environment and inhibition of proteasome could be the reason of their cytotoxic effect.

The normal progression of cell cycle is the result of a regulated interaction between cyclins and cyclins dependent kinases (CDKs). The disruption of this regulation contributes to tumor developments, since cells go into uncontrolled proliferation. ${ }^{86}$ Different proteins involved in cell cycle progression are degraded by UPS system, ${ }^{87}$ suggesting that proteasome inhibition may induce cell cycle arrest. Complexes 4 and 8 induced cell cycle arrest in Gi phase after $24 \mathrm{~h}$ incubation (Figure 13), whereas cells treated with complex 9 showed no significant changes, which is in accordance with its lowest CT-like activity inhibition (Figure 12). Determination of cell cycle status by flow cytometry confirmed proteasome as a possible target of our complexes.

In this way, $\mathrm{p} 27^{\mathrm{Kip} 1}$ is a cyclin-dependent kinase inhibitor (CKI) which arrest cell cycle in Gi phase, negatively regulating cell-cycle progression. In the nucleus, $\mathrm{p}_{2} 7^{\text {Kip1 }}$ binds cyclin E/Cdk2 complex, preventing this complex from activating the transcription of different genes involved in G1-S transition. ${ }^{88}$ Tumor suppressor function of p27 can reverse in case of its degradation by UPS in the nucleus, ${ }^{89}$ which dysregulate cell cycle, inducing cell proliferation..$^{90}$ In addition, nuclear p2 $7^{\text {Kip1 }}$ binding to cyclin E/Cdk2 complex is mediated by NF$\kappa \mathrm{B}$, which binds the complex preventing the interaction with the CKI. ${ }^{91} \mathrm{NF}-\kappa \mathrm{B}$ signalling is regulated by UPS, since inhibitory $\kappa \mathrm{B}(\mathrm{I} \kappa \mathrm{B})$ is ubiquitined and proteolyzed by the proteasome, allowing NF- $\kappa B$ to enter the nucleus. ${ }^{92}$ In conclusion, proteasome inhibition will prevent nuclear p2 $7^{\text {Kip1 }}$ loss, thus inducing cell cycle arrest in Go/G1 phase, ${ }^{25}$ which correlates with results shown in Figure 12 and Figure 13.

\section{CONCLUSIONS}

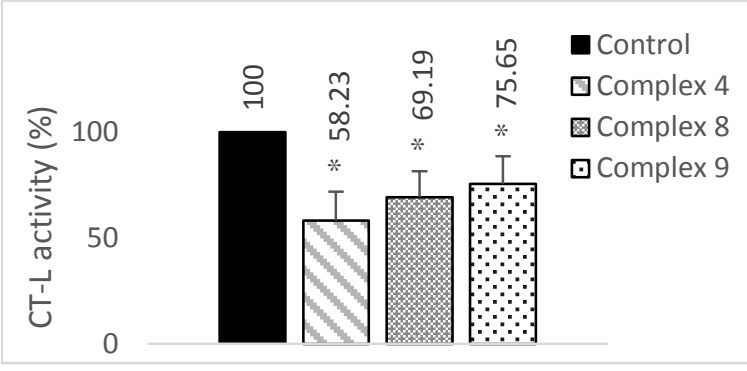

Figure 12. Determination of proteasomal chymotrypsin-like activity inhibition. Colon cancer Caco-2/TC7 cells were treated with complexes $4(1.18 \mu \mathrm{M}) \mathbf{8}(1 \mu \mathrm{M})$ and $9(5 \mu \mathrm{M})$ for 24 h. CT-L activity was determined by measuring fluorescence after cleavage of N-Suc-L-L-V-T-AMC and the results are expressed in terms of \% of activity with respect to control. Activity ${ }^{*} \mathrm{p}<0.05$ compared to control.

In this study we report the synthesis of new mixed thiolatedithiocarbamate gold(III) derivatives via transmetalation reactions with tin(IV) complexes. These new derivatives display high antiproliferative effect on colon cancer cells and reduce cell viability mainly by intrinsic apoptotic pathway since they produce modification of mitochondrial membrane potential, release of cytochrome $\mathrm{c}$ to the cytoplasm and caspase 3 activation. Likewise, the proteasome could be the cellular target of these complexes, which is supported by our experiments. Moreover, this fact would explain the cell cycle arrest in G1 phase, since different proteins related with cell cycle progression and regulation need to be degraded by UPS system before exerting their function. On the other hand, although TrxR was studied as a potential target for our complexes, different experiments in cells rejected this hypothesis, since ROS levels and TrxR activity seemed to be maintained unaltered. Although cytotoxicity is scarcely affected by the different thiolates in the structure, the substituents in the dithiocarbamate unit exert a greater influence, being ethyl group the most active. In addition, higher cytotoxicity is exerted by the complexes in comparison to the free ligands, which is in accordance with the relevance of the metal presence. Some of these complexes have proved to be selective towards normal enterocytes, displaying viabilities around ${ }_{100} \%$ in Caco-2 cells under confluence, as well as higher $\mathrm{IC}_{50}$ values towards other differentiated cells (Hep G-2) than in tumor cell lines (Caco-2/ $/ \mathrm{TC}_{7}$ and $\mathrm{MCF}-7$ ). We have found that their interaction with BSA led to moderate binding constants, which suggests their transportation by the protein through blood and easy target release. In addition, their stability under physiological conditions even towards biological relevant reducing agents, such as sodium ascorbate makes them suitable candidates for drug development in colorectal cancer treatment.

\section{EXPERIMENTAL SECTION}

\subsection{General procedures}

${ }^{1} \mathrm{H},{ }^{31} \mathrm{P}\left\{{ }^{1} \mathrm{H}\right\}$ (161.97 MHz) and ${ }^{13} \mathrm{C}\left\{{ }^{1} \mathrm{H}\right\}$ (100.62 or $75.4 \mathrm{MHz}$ ) NMR spectra were recorded on $400 \mathrm{MHz}$ or $300 \mathrm{MHz}$ Bruker Advance spectrometers. Chemical shifts are quoted in ppm 
relative to external TMS $\left({ }^{1} \mathrm{H},{ }^{13} \mathrm{C}\right)$ or $85 \% \mathrm{H}_{3} \mathrm{PO}_{4}\left({ }^{31} \mathrm{P}\right)$; coupling constants are reported in hertz.

IR spectra were recorded on a Perkin-Elmer Spectrum 100 FTIR (far-IR) spectrophotometer. Elemental analyses were obtained in-house using a LECO CHNS-932 microanalyzer. Gold(III) $\left[\mathrm{AuCl}_{2}\left(\mathrm{~S}_{2} \mathrm{CNR}_{2}\right)\right](\mathrm{R}=\mathrm{Me}, \mathrm{Et}, \mathrm{Bz})$ were prepared as described in the literature. ${ }^{93}$ The thiolato tin(IV) compounds $\left[\mathrm{SnMe}_{2}(\mathrm{SR})\right] \quad(\mathrm{SR}=$ Spirimidine, SMepirimidine, $\mathrm{SMe}_{2}$ pirimidine) were prepared similarly to previously described complexes). ${ }^{94-95}$

4.2. General synthesis of $\left[\mathrm{Au}(\mathrm{SR})_{2}\left(\mathrm{~S}_{2} \mathrm{CNR} \mathrm{R}_{2}\right)\right]\left(\mathrm{SR}=\mathrm{Spyrim} ; R^{\prime}=\right.$ Me, 1; $R^{\prime}=E t, 2 ; R^{\prime}=B z, 3 ; S R=S M e p y r i m ; R^{\prime}=M e, 4 ; R^{\prime}=E t$, 5; $R^{\prime}=B z, 6 ; S R=S M e_{2}$ pyrim; $\left.R^{\prime}=M e, 7 ; R^{\prime}=E t, 8 ; R^{\prime}=B z, 9\right)$

To a solution of $\left[\mathrm{AuCl}_{2}\left(\mathrm{~S}_{2} \mathrm{CNR}_{2}\right)\right](0.25 \mathrm{mmol})$ in acetone (ca. $20 \mathrm{~mL})\left[\mathrm{Sn}(\mathrm{SR})_{2} \mathrm{Me}_{2}\right](0.25 \mathrm{mmol})$ was added. After stirring the mixture for $c a .4 \mathrm{~h}$ at room temperature the solutions were concentrated under vacuum. Addition of $\mathrm{Et}_{2} \mathrm{O}$ allowed the precipitation of the products, which were isolated by filtration and dried in air.

Using this method the following complexes were prepared:

[Au(Spyrim $\left.)_{2}\left(\mathrm{~S}_{2} \mathrm{CNMe}_{2}\right)\right]$ (1). Dark yellow solid in $73 \%$ yield. ${ }^{1} \mathrm{H}$ NMR (40o $\left.\mathrm{MHz}, \mathrm{CDCl}_{3},{ }^{2} 5^{\circ} \mathrm{C}\right): \delta(\mathrm{ppm})=8.41\left(\mathrm{~d}, 4 \mathrm{H}, J_{H-H}\right.$ $=4.8 \mathrm{~Hz}$, Spyrim), $6.85\left(\mathrm{t}, 2 \mathrm{H}, J_{H-H}=4.8 \mathrm{~Hz}\right.$, Spyrim $), 3.36(\mathrm{~s}$, $6 \mathrm{H}, \mathrm{Me}(\mathrm{dtc})),{ }^{13} \mathrm{C}\left\{{ }^{1} \mathrm{H}\right\} \mathrm{NMR}\left(75.4 \mathrm{MHz}, \mathrm{CDCl}_{3}\right): \delta(\mathrm{ppm})=154.6$ (Spyrim), 144.2, 131.8, 128.0, 124.0, 113.8, 111.9 (Spyrim), 22.2 (Me(dtc)). I.R.: v(NCSS): $1541 \mathrm{~cm}^{-1}, v(\mathrm{SCS}): 983 \mathrm{~cm}^{-1}$; v(SAuS): $385,427 \mathrm{~cm}^{-1} . \mathrm{C}_{11} \mathrm{H}_{12} \mathrm{AuN}_{5} \mathrm{~S}_{4}$ (538.964): $\mathrm{C} 24.49, \mathrm{H} 2.24, \mathrm{~N}$ 12.98, found: $\mathrm{C} 24.83, \mathrm{H} 2.39, \mathrm{~N} 12.67 . \log D_{7.4}=0.62$.

$\left[\mathrm{Au}(\text { Spyrim })_{2}\left(\mathrm{~S}_{2} \mathrm{CNEt}_{2}\right)\right]$ (2). Red solid in $62 \%$ yield. ${ }^{1} \mathrm{H}$ NMR $\left(400 \mathrm{MHz}, \mathrm{CDCl}_{3}, 25^{\circ} \mathrm{C}\right): \delta(\mathrm{ppm})=8.41\left(\mathrm{~d}, 4 \mathrm{H}, J_{\mathrm{H}-\mathrm{H}}=4.8 \mathrm{~Hz}\right.$, Spyrim), $6.85\left(\mathrm{t}, 2 \mathrm{H}, J_{H-H}=4.8 \mathrm{~Hz}, \operatorname{Spyrim}\right), 3.71\left(\mathrm{q}, 4 \mathrm{H}, J_{H-H}=\right.$ $\left.7.2 \mathrm{~Hz}, \mathrm{CH}_{2}(d t c)\right), 1.37\left(\mathrm{t}, 6 \mathrm{H}, J_{H-H}=7.2 \mathrm{~Hz}, \mathrm{Me}(d t c)\right) .{ }^{13} \mathrm{C}\left\{{ }^{1} \mathrm{H}\right\}$ NMR (75.4 MHz, $\left.\mathrm{CDCl}_{3}\right): \delta(\mathrm{ppm})=195.4$ (CSS), 157.6; 118.3, 115.8 (Spyrim), $45.4\left(\mathrm{CH}_{2}(d t c)\right), 12.5(\mathrm{Me}(d t c))$. I.R.: v(NCSS): $1539 \mathrm{~cm}^{-1}, \quad v(\mathrm{SCS}): 1068 \mathrm{~cm}^{-1} ; \mathrm{v}(\mathrm{SAuS}): 38 \mathrm{o}, 416 \mathrm{~cm}^{-1}$.

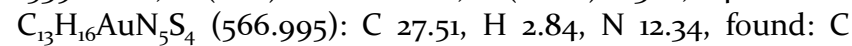
27.16, H 3.11, N 12.42. $\log D_{7.4}=0.73$.

$\left[\mathrm{Au}(\text { Spyrim })_{2}\left(\mathrm{~S}_{2} \mathrm{CNBz}_{2}\right)\right]$ (3). Red solid in $64 \%$ yield. ${ }^{1} \mathrm{H}$ NMR $\left(400 \mathrm{MHz}, \mathrm{CDCl}_{3}, 25^{\circ} \mathrm{C}\right): \delta(\mathrm{ppm})=8.42\left(\mathrm{~d}, 4 \mathrm{H}, J_{H-H}=4.8 \mathrm{~Hz}\right.$, Spyrim), $7.40(\mathrm{~m}, 10 \mathrm{H}, B z(d t c)), 6.86\left(\mathrm{t}, 2 \mathrm{H}, J_{H-H}=4.8 \mathrm{~Hz}\right.$, Spyrim), $4.73\left(\mathrm{~s},{ }_{4} \mathrm{H}, B z(d t c)\right) .{ }^{13} \mathrm{C}\left\{{ }^{1} \mathrm{H}\right\}$ NMR $(75.4 \mathrm{MHz}$, $\left.\mathrm{CDCl}_{3}\right): \delta(\mathrm{ppm})=156.6$ (Spyrim), 203.9 (CSS), 178.1, 134.2, 132.0, 129.4, 128.9, 127.6 (Bz (dtc)), 115.9 (Spyrim), 52.1 $(B z(d t c))$. I.R.: v(NCSS): $1450 \mathrm{~cm}^{-1}, \mathrm{v}(\mathrm{SCS}): 976 \mathrm{~cm}^{-1}$; v(SAuS): 317, $420 \mathrm{~cm}^{-1} . \mathrm{C}_{23} \mathrm{H}_{20} \mathrm{AuN}_{5} \mathrm{~S}_{4}$ (691.027): $\mathrm{C}_{39.94}, \mathrm{H} 2.91, \mathrm{~N} 10.13$, found: $\mathrm{C}_{39.55}, \mathrm{H}$ 3.21, $\mathrm{N}$ 9.72. $\log D_{7.4}=0.99$.

$\left[\mathrm{Au}(\mathrm{SMepyrim})_{2}\left(\mathrm{~S}_{2} \mathrm{CNMe}_{2}\right)\right]$ (4). Dark yellow solid in $80 \%$ yield. ${ }^{1} \mathrm{H}$ NMR (40o $\left.\mathrm{MHz}, \mathrm{CDCl}_{3}, 25^{\circ} \mathrm{C}\right): \delta(\mathrm{ppm})=8.27(\mathrm{~d}, 2 \mathrm{H}$, $J_{H-H}=5.1 \mathrm{~Hz}$, SMepyrim $), 6.71\left(\mathrm{~d}, 2 \mathrm{H}, J_{H-H}=5.1 \mathrm{~Hz}\right.$, SMepyrim), 3.35 (s, 6H, Me(dtc)). I.R.: v(NCSS): $1585 \mathrm{~cm}^{-1}$, $v(\mathrm{SCS}): 990 \mathrm{~cm}^{-1} ; \mathrm{v}(\mathrm{SAuS}): 383,438 \mathrm{~cm}^{-1} \cdot \mathrm{C}_{13} \mathrm{H}_{16} \mathrm{AuN}_{5} \mathrm{~S}_{4}$ (566.995): $\mathrm{C}$ 27.51, H 2.84, N 12.34, found: $\mathrm{C} 27.21, \mathrm{H} 3.23, \mathrm{~N}$ 12.46. $\log D_{7.4}=0.66$.

[Au(SMepyrim $\left.)_{2}\left(\mathrm{~S}_{2} \mathrm{CNEt}_{2}\right)\right]$ (5). Red solid in $60 \%$ yield. ${ }^{1} \mathrm{H}$ NMR (40O MHz, $\left.\mathrm{CDCl}_{3}, 25^{\circ} \mathrm{C}\right): \delta(\mathrm{ppm})=8.28\left(\mathrm{~d},{ }_{4} \mathrm{H}, J_{H-H}=\right.$ $5.1 \mathrm{~Hz}, S M e p y r i m), 6.71\left(\mathrm{~d}, 2 \mathrm{H}, J_{H-H}=5.1 \mathrm{~Hz}, S M e p y r i m\right), 3.71$ (q, $\left.4 \mathrm{H}, J_{H-H}=7.2 \mathrm{~Hz}, C_{2}(d t c)\right), 1.37\left(\mathrm{t}, 6 \mathrm{H}, J_{H-H}=9.5,5.0 \mathrm{~Hz}\right.$, $\mathrm{Me}(d t c)) .{ }^{13} \mathrm{C}\left\{{ }^{1} \mathrm{H}\right\} \operatorname{NMR}\left(75.4 \mathrm{MHz}, \mathrm{dmso}-d_{6}\right): \delta(\mathrm{ppm})=150.2$
(Spyrim), 194.3 (CSS), 116.5 (Spyrim), 47.02, 12.6 (Et(dtc)), 23.4 (Me). I.R.: v(NCSS): $1558 \mathrm{~cm}^{-1}, \mathrm{v}(\mathrm{SCS}): 1070 \mathrm{~cm}^{-1} ; \mathrm{v}(\mathrm{SAuS}): 381$, $417 \mathrm{~cm}^{-1} . \mathrm{C}_{15} \mathrm{H}_{20} \mathrm{AuN}_{5} \mathrm{~S}_{4}$ (595.027): C 30.25, H 3.38, N 11.76, found: $\mathrm{C}$ 29.86, $\mathrm{H}$ 3.41, $\mathrm{N}$ 11.44. $\log D_{7.4}=1.11$.

[Au(SMepyrim $\left.)_{2}\left(\mathrm{~S}_{2} \mathrm{CNBz}_{2}\right)\right]$ (6). Red solid in $60 \%$ yield. ${ }^{1} \mathrm{H}$ NMR (40o MHz, $\left.\mathrm{CDCl}_{3}, 25^{\circ} \mathrm{C}\right): \delta(\mathrm{ppm})=8.29\left(\mathrm{~d}, 2 \mathrm{H}, J_{H-H}=\right.$ $4.3 \mathrm{~Hz}$, SMepyrim), $7.42(\mathrm{~m}, 1 \mathrm{OH}, B z(d t c)), 6.71\left(\mathrm{~d}, 2 \mathrm{H}, J_{H-H}=\right.$ $4.3 \mathrm{~Hz}$, SMepyrim), $4.73(\mathrm{~s}, 4 \mathrm{H}, B z(d t c)), 2.40(\mathrm{~s}, 6 \mathrm{H}$, SMepyrim). ${ }^{13} \mathrm{C}\left\{{ }^{1} \mathrm{H}\right\}$ NMR (101 MHz, $\left.\mathrm{CDCl}_{3}\right): \delta(\mathrm{ppm})=203.9$ (CSS), 134.5, (Bz(dtc)), 128.1 (SMepyrim), 128.9, 127.6 Bz(dtc)), $58.6(B z(d t c))$, $30.8(M e), 12.9$ (s, Et). I.R.: v(NCSS): $1526 \mathrm{~cm}^{-1}$, $v($ SCS $): 1083 \mathrm{~cm}^{-1} ; v(\mathrm{SAuS}): 346,416 \mathrm{~cm}^{-1} . \mathrm{C}_{25} \mathrm{H}_{24} \mathrm{AuN}_{5} \mathrm{~S}_{4}$ (719.058): $\mathrm{C}$ 41.72, $\mathrm{H}$ 3.36, $\mathrm{N}$ 9.73, found: $\mathrm{C} 41.36, \mathrm{H} \mathrm{3.42,} \mathrm{N}$ 9.48. $\log D_{7.4}=1.03$.

$\left[\mathrm{Au}\left(\mathrm{SMe}_{2} \text { pyrim }\right)_{2}\left(\mathrm{~S}_{2} \mathrm{CNMe}_{2}\right)\right]$ (7). Dark yellow solid in $90 \%$ yield. ${ }^{1} \mathrm{H} \mathrm{NMR}\left(400 \mathrm{MHz}, \mathrm{CDCl}_{3}, 25^{\circ} \mathrm{C}\right): \delta(\mathrm{ppm})=6.56(\mathrm{~s}, 2 \mathrm{H}$, SMe $e_{2}$ pyrim), 3.35 (s, 6H, Me(dtc)), 2.35 (s, 12H, SMe $e_{2}$ pyrim). ${ }^{13} \mathrm{C}\left\{{ }^{1} \mathrm{H}\right\}$ NMR $\left(75.4 \mathrm{MHz}, \mathrm{CDCl}_{3}\right): \delta(\mathrm{ppm})=202.8(\mathrm{CSS}), 166.6$ $(\mathrm{Me}(\mathrm{dtc}))$, 115.1 (SMe $_{2}$ yrim), 39.1 (Me(dtc)), 23.6 (SMe ${ }_{2}$ pyrim). I.R.: v(NCSS): $1568 \mathrm{~cm}^{-1}, \mathrm{v}(\mathrm{SCS}): 968 \mathrm{~cm}^{-1} ; \mathrm{v}(\mathrm{SAuS}): 381,439$ $\mathrm{cm}^{-1} . \mathrm{C}_{15} \mathrm{H}_{20} \mathrm{AuN}_{5} \mathrm{~S}_{4}$ (595.027): $\mathrm{C}_{30.25}, \mathrm{H} 3.38, \mathrm{~N}$ 11.76, found: C 29.86, H 3.42, N 11.36. $\log D_{7.4}=1.52$.

$\left[\mathrm{Au}\left(\mathrm{SMe}_{2} \mathrm{Pyrim}_{2}\left(\mathrm{~S}_{2} \mathrm{CNEt} \mathrm{t}_{2}\right)\right](\boldsymbol{8})\right.$. Red solid in $55 \%$ yield. ${ }^{1} \mathrm{H}$ NMR (400 MHz, $\left.\mathrm{CDCl}_{3}, 25^{\circ} \mathrm{C}\right): \delta(\mathrm{ppm})=6.57(\mathrm{~d}, 2 \mathrm{H}$, $S M e_{2}$ pyrim), $3.71\left(\mathrm{q},{ }_{4} \mathrm{H}, J_{\mathrm{H}-\mathrm{H}}=7.2 \mathrm{~Hz}, \mathrm{CH}_{2}(d t c)\right), 2.36(\mathrm{~s}, 12 \mathrm{H}$, $S M e_{2}$ pyrim $), 1.37\left(\mathrm{t}, 6 \mathrm{H}, J_{\mathrm{H}-\mathrm{H}}=9.5,5.0 \mathrm{~Hz}, \mathrm{Me}(d t c)\right) .{ }^{13} \mathrm{C}\left\{{ }^{1} \mathrm{H}\right\}$ $\operatorname{NMR}\left(101 \mathrm{MHz}, \mathrm{CDCl}_{3}\right): \delta(\mathrm{ppm})=195.2(\mathrm{CSS}), 166.6$, 115.01

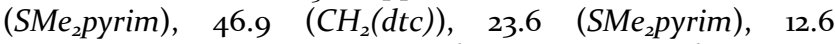
(Me(dtc)). I.R.: v(NCSS): $1528 \mathrm{~cm}^{-1}, v(\mathrm{SCS}): 1071 \mathrm{~cm}^{-1}$; v(SAuS): $383,428 \mathrm{~cm}^{-1} . \mathrm{C}_{17} \mathrm{H}_{24} \mathrm{AuN}_{5} \mathrm{~S}_{4}$ (623.058): $\mathrm{C} 32.74, \mathrm{H} 3.88, \mathrm{~N}$ 11.23, found: $\mathrm{C} 32.35, \mathrm{H} 3.52, \mathrm{~N} 11.42 . \log D_{7.4}=1.51$.

$\left[\mathrm{Au}\left(\mathrm{SMe}_{2} \text { pyrim }\right)_{2}\left(\mathrm{~S}_{2} \mathrm{CNBz}_{2}\right)\right]$ (9). Red solid in $65 \%$ yield. ${ }^{1} \mathrm{H}$

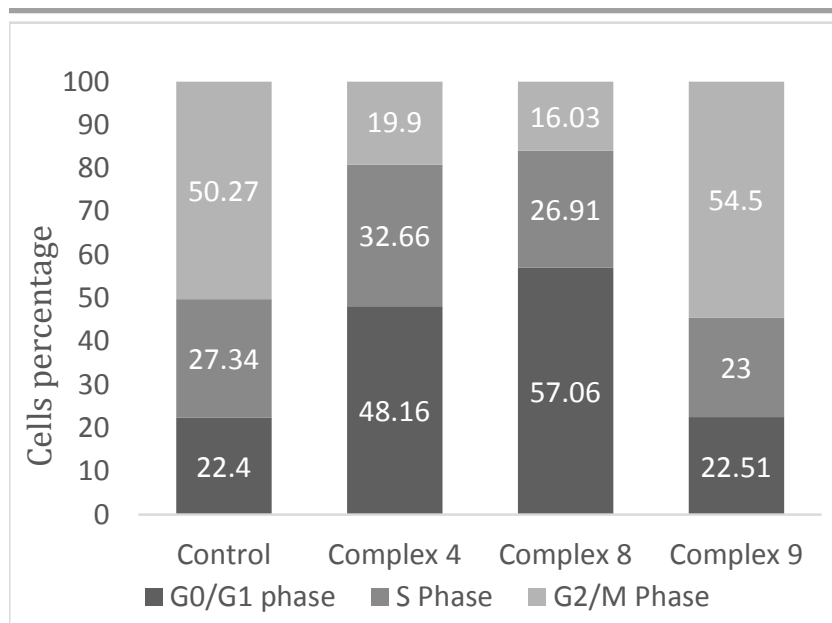

Figure 13. Cell cycle analyses by flow cytometry. Cancer Caco2/TC7 cells were incubated with complexes $\left[\mathrm{Au}(\mathrm{SMepyrim})_{2}\left(\mathrm{~S}_{2} \mathrm{CNMe}_{2}\right)\right] \quad$ (4) $\quad(1.18 \quad \mu \mathrm{M})$, $\left[\mathrm{Au}\left(\mathrm{SMe}_{2} \text { pyrim }\right)_{2}\left(\mathrm{~S}_{2} \mathrm{CNEt}_{2}\right)\right] \quad$ (8) $\quad(1 \quad \mu \mathrm{M}) \quad$ and $\left[\mathrm{Au}\left(\mathrm{SMe}_{2} \text { pyrim }\right)_{2}\left(\mathrm{~S}_{2} \mathrm{CNBz}_{2}\right)\right](9)(5 \mu \mathrm{M})$ for $24 \mathrm{~h}$. Cells were stained with PI and fluorescence was determined by flow cytometry. The results are expressed in terms of \% of cells in each phase of the cell cycle. 
NMR (400 $\left.\mathrm{MHz}, \mathrm{CDCl}_{3},{ }^{\circ} 5^{\circ} \mathrm{C}\right): \delta(\mathrm{ppm})=7.41(\mathrm{~m}, 10 \mathrm{H}$,

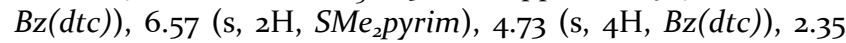
(s, 6H, SMe $e_{2}$ pyrim). ${ }^{13} \mathrm{C}\left\{{ }^{1} \mathrm{H}\right\}$ NMR $\left(75.4 \mathrm{MHz}, \mathrm{CDCl}_{3}\right): \delta(\mathrm{ppm})$ = 195.4 (CSS), 166.7, 132.4, 129.5, 129.0, 128.5, $127.6(B z(d t c))$, 115.2 (SMe $e_{2}$ pyrim), 52.1 (Bz(dtc)), 23.6 (SMe 2 pyrim). I.R.: v(NCSS): $1519 \mathrm{~cm}^{-1}, \mathrm{v}(\mathrm{SCS}): 1078 \mathrm{~cm}^{-1} ; \mathrm{v}(\mathrm{SAuS}): 365,422 \mathrm{~cm}^{-1}$. $\mathrm{C}_{27} \mathrm{H}_{28} \mathrm{AuN}_{5} \mathrm{~S}_{4}$ (747.089): $\mathrm{C}$ 43.37, $\mathrm{H}$ 3.77, $\mathrm{N}$ 9.37, found: $\mathrm{C}$ 42.96, H 3.54, N 9.13. $\log D_{7.4}=0.80$.

\subsection{X-Ray crystallography.}

Crystals were mounted in inert oil on glass fibers and transferred to the cold gas stream of an Xcalibur Oxford Diffraction diffractometer equipped with a low-temperature attachment. Data were collected using monochromated MoK $\alpha$ radiation $(\lambda=0.71073 \AA)$. Scan type $\omega$. Absorption corrections based on multiple scans were applied using spherical harmonics implemented in SCALE3 ABSPACK scaling algorithm. ${ }^{96}$ The structures were solved by direct methods and refined on F2 using the program SHELXL-97. ${ }^{97}$ All nonhydrogen atoms were refined anisotropically. Further details on the crystal refinements are collected in Table S1. CCDC 1822691 (7) and 1822692 (9) contain the supplementary crystallographic data. These data can be obtained free of charge by The Cambridge Crystallography Data Center.

4.4. Distribution coefficient $\left(\log D_{7.4}\right)$. The n-octanol-water coefficients of the complexes were determined using a shakeflask method. ${ }^{29}$ Briefly: buffered-saline distilled water (10o $\mathrm{mL}$, phosphate buffer $\left[\mathrm{PO}_{4}^{3^{-}}\right]=10 \mathrm{mM},[\mathrm{NaCl}]=0.15 \mathrm{M}, \mathrm{pH}$ 7.4) and n-octanol (10o $\mathrm{mL}$ ) were shaken together for $72 \mathrm{~h}$ to allow saturation of both phases. The addition of $1 \mathrm{mg}$ of the complexes followed by centrifugation and separation of both phases gave two solutions of such derivatives which were analyzed by UV absorbance spectroscopy to determine their concentration. $\quad \log D_{7.4} \quad$ was defined as $\log \left\{\left[\right.\right.$ compound $\left._{(\text {organic) }}\right] /\left[\right.$ compound $\left.\left._{\text {(aqueous) }}\right]\right\}$.

4.5. Solution chemistry. The stability of the gold complexes has been analyzed by absorption UV spectroscopy. UV-Vis absorption spectra of the complexes were recorded on a Thermo Scientific spectrophotometer. Solutions of the thiolate complexes were prepared from their $20 \mathrm{mM}$ DMSO or $\mathrm{MeCN}$ stock solutions. Final concentration of these complexes $\left(5 \times 10^{-5} \mathrm{M}\right)$ in PBS $(\mathrm{pH}=7.4)$ were made up to a volume of $15 \mathrm{~mL}$. The final concentration of DMSO or MeCN in the test cell was $0.5 \%$. The samples were then incubated at $37^{\circ} \mathrm{C}$ and thereafter monitored measuring the electronic spectra over $24 \mathrm{~h}$. Their stability towards reduction was measured by UVvis spectroscopy after the addition of a solution of sodium ascorbate in a molar ratio $1: 10$ to a $2.5 \cdot 10^{-5} \mathrm{M}$ solution of the gold derivatives

4.6. Interaction with bovine serum albumin. $2 \mathrm{mM}$ stock solution of BSA was prepared in PBS at $\mathrm{pH}$ 7.4. The real concentration was confirmed using UV-Vis spectroscopy $\left(\varepsilon_{280 \mathrm{~nm}}=\right.$ $43824 \mathrm{M}^{-1} \mathrm{~cm}^{-1}$ ). UV-visible spectra were recorded by scanning in the wavelength range of $200-400 \mathrm{~nm}$. The BSA concentration was fixed at $10 \mathrm{mM}$, while that of complex 1 was varied from $10 \mathrm{mM}$ to $60 \mathrm{mM}$. The absorbance due to the complex was nullified by its addition in the reference cell at the same increasing concentration (from $10 \mathrm{mM}$ to $60 \mathrm{mM}$ ). An additional mixture of BSA (10 $\mathrm{mM}$ ) and complex 1 (10 $\mathrm{mM}$ ) was incubated and measured the corresponding UV-vis spectrum after dialysis by using an Amicon ${ }^{\circledR}$ Ultra-15 10K Centrifugal Filter device.

For luminescence experiments:

BSA dialysis. A $6 \mathrm{mM}$ solution of complex 8 in $\mathrm{MeCN}$ was prepared and diluted in PBS to obtain a final concentration of $60 \mathrm{mM}$. a dialysis membrane containing $8 \mathrm{~mL}$ of a solution of BSA $50 \mathrm{mM}$ was immersed in $50 \mathrm{~mL}$ of the complex solution in a beaker. The BSA was then dialyzed against the complex solution for 24 h at $5{ }^{\circ} \mathrm{C}$. Thereafter the luminescence of BSA was analysed by fluorescence spectroscopy after excitation at $290 \mathrm{~nm}$.

BSA quenching experiments. Gold complexes were dissolved in DMSO to achieve $6 \mathrm{mM}$ stock solutions and six aliquots of 2.5 $\mu \mathrm{L}$ were added to a $50 \mu \mathrm{M}$ solution of BSA in PBS placed in a quartz cuvette of $1 \mathrm{~cm}$ optical path. The final concentrations of gold complexes in the cuvette were o, 5, 10, 15, 20, 25 and $30 \mu \mathrm{M}$. The fluorescence spectra were recorded on a Jobin-Yvon-Horiba fluorolog FL-3-11 spectrometer. The samples were excited at $290 \mathrm{~nm}$ and the emission spectra were recorded in a range from 310 to $450 \mathrm{~nm}$ with emission slits set to $2 \mathrm{~nm}$. The fluorescence was measured 4 min after every addition of the aliquots of gold complexes.

The data were analyzed using the Stern-Volmer equation $F_{o} / F=1+K_{S V}$ [gold complex] $=1+K_{q} \tau_{o}$ [gold complex] $\left(\tau_{o}=\right.$ lifetime of BSA in absence of the quencher) in order to obtain the Stern-Volmer quenching constant $\left(\mathrm{K}_{\mathrm{sv}}\right)$ and the quenching rate constant $\left(\mathrm{K}_{\mathrm{q}}\right)$. The binding constant $\left(\mathrm{K}_{\mathrm{b}}\right)$ was quantified by using the modified Stern-Volmer equation: log $\left\{\left(F_{o}-F\right) / F\right\}=\log K_{b}+n \log$ [gold complex] ( $n=$ number of binding sites). ${ }^{98-99}$

4.7. Cell culture. Human colon cancer Caco-2 cells $\left(\mathrm{TC}_{7}\right.$ clone) were kindly provided by Dr. Edith Brot-Laroche (Université Pierre et Marie Curie-Paris 6, UMR S 872, Les Cordeliers, France) and grown in Dulbecco's Modified Eagles medium (DMEM) (Gibco Invitrogen, Paisley, UK) supplemented with $20 \%$ fetal bovine serum (FBS), $1 \%$ non-essential amino acids, $1 \%$ streptomycin $(1000 \mu \mathrm{g} / \mathrm{mL}), 1 \%$ penicillin (1000 $\mu \mathrm{g} / \mathrm{mL})$ and $1 \%$ amphotericin $(250 \mathrm{U} / \mathrm{mL})$. Caco-2 cells were maintained at $37^{\circ} \mathrm{C}$ in a humidified atmosphere of $5 \% \mathrm{CO}_{2}$.

Human MCF-7 cell line was kindly provided by Dr. Carlos J. Ciudad and Dr. Veronica Noé (Departamento de Bioquimica y Fisiología, Facultad de Farmacia, Universidad de Barcelona, Spain). HepG2 cell line was kindly provided by Dr. María Angeles Alava (Departamento de Bioquimica y Biología Molecular, Facultad de Ciencias, Universidad de Zaragoza, Spain). MCF-7 and HepG2 cells were maintained in the same conditions as described for Caco-e cell line.

4.8. Cell proliferation assay. Cell proliferation was measured using the 3-(4,5-dimethyl-2-thiazoyl)-2,5diphenyltetrazolium bromide (MTT) assay. ${ }^{100}$ Cells were seeded in a 96-well plate at a density of 4000 cells/well and grown for $24 \mathrm{~h}$ before treating them with each complex or DMSO (used as control). After $72 \mathrm{~h}$ incubation with the complexes $10 \mu \mathrm{L}$ of MTT $(5 \mathrm{mg} / \mathrm{mL}$ ) were added and incubation was continued at $37^{\circ} \mathrm{C}$ for $3 \mathrm{~h}$. Medium was then removed by inversion and $100 \mu \mathrm{L}$ of DMSO were added to each well. Absorbance at $560 \mathrm{~nm}$, proportional to number of living cells, was measured by spectrophotometry (SPECTROstar Nano, BMG LABTECH) and converted into percentage (\%) of growth inhibition. 


\section{ASSOCIATED CONTENT}

\section{Supporting Information}

Experimental procedures corresponding to apoptosis, caspase 3, cytochrome c and cell cycle determinations; mitochondrial membrane potential; ROS determination; interaction with TrxR and proteasome; docking and DFT analysis are included in the supporting information. In addition, UV-Vis spectra from stability assays, BSA fluorescence quenching spectra, X-Ray data and list of Cartesian coordinates, Cells viability ( $\left.\mathrm{IC}_{5} \mathrm{O}\right)$ of breast (MCF-7) and liver (HepG2) in the presence of complex 8 are available free of charge via the Internet at http://pubs.acs.org..

\section{AUTHOR INFORMATION}

\section{Corresponding Author}

Dr. E. Cerrada. Departamento de Química Inorgánica, Instituto de Síntesis Química y Catálisis Homogénea-ISQCH, Universidad de Zaragoza-C.S.I.C., 50009 Zaragoza, Spain; Email: ecerrada@unizar.es

Dr. Ma Jesús Rodrigez Yoldi. Departamento de Farmacología y Fisiología. Unidad de Fisiología, Facultad de Veterinaria, Universidad de Zaragoza, 50o13, Zaragoza, CIBERobn, IIS Aragón IAz, Spain.E-mail: mirodyol@unizar.es

\section{Notes}

The authors declare no competing financial interests.

\section{ACKNOWLEDGMENT}

Authors thank to Centro de Investigación Biomédica de Aragón (CIBA), España for technical assistance: http://www.iacs.aragon.es, use of Servicio General de Apoyo a la Investigación-SAI, Universidad de Zaragoza. We thank Pablo Palau Irisarri for the technical assistance in the preparation of graphical abstract. We thank The Ministerio de Economia y Competitividad (CTQ2016-75816-C2-1-P and SAF2016-75441-R) and DGA (A-32 and E104) for financial support.

\section{ABBREVIATIONS}

APAF-1, Apoptosis protease-activating factor-1; BSA, Bovine serum albumin; CDK, cyclin dependent kinase; CT-L, chymotryspsin-like activity, CKI, Cyclin-dependent kinase inhibitor; DCFH-DA, 2,7-dichlorodihydrofluorescein diacetate; DCTB, trans-2-[3-(4-tert-butylphenyl)-2-methyl-2-

propenylidene]malononitrile; DMEM, Dubelcco's Modified Eagle Medium; DMSO, Dimethylsulfoxide; DTNB, 5,5'dithiobis(2-nitrobenzoic) acid; EDTA, Ethylenediaminetetraacetic acid; FBS, Fetal bovine serum; FITC, Flourescein isothiocyanate; FT-IR, Fourier Transform Infrared Spectroscopy; HSA, human serum albumin; IкB, Inhibitory $\kappa \mathrm{B}$; MMP, mitochondrial membrane potential; MTT, 3-(4,5-dimethyl-2thiazoyl)-2,5-diphenyltetrazolium bromide; NF- $\kappa$ B, Nuclear factor kappa-light-chain-enhancer of activated B cells; PBS, phosphate-buffered saline; PCM, Polarizable continuum model; PI, Propidium iodide; Pyrim, pyrimidine; PLP, Piecewise linear potential;ROS, Reactive Oxygen Species; Trp, tryptophan; TrxR, thioredoxin reductase. UPS, ubiquitin/proteasome system

\section{REFERENCES}

1. Haas, K. L.; Franz, K. J., Application of Metal Coordination Chemistry To Explore and Manipulate Cell Biology. Chem. Rev 2009, 109 (10), 4921-4960.

2. Frezza, M.; Hindo, S.; Chen, D.; Davenport, A.; Schmitt, S.; Tomco, D.; Dou, Q. P., Novel Metals and Metal Complexes as Platforms for Cancer Therapy. Curr. Pharm. Des. 2010, 16 (16), 1813-1825.

3. Dorr, R. T., A review of the modulation of cisplatin toxicities by chemoprotectants. In Platinum And Other Metal Coordination Compounds In Cancer Chemotherapy 2, Pinedo, H. M.; Schomagel, J. H., Eds. Plenum Press: New York, 1996; pp 131-154.

4. Segovia, N.; Crovetto, G.; Lardelli, P.; Espigares, M., In vitro toxicity of several dithiocarbamates and structureactivity relationships. J. Appl. Toxicol. 2002, 22 (6), 353-357.

5. Nardon, C.; Brustolin, L.; Fregona, D., Is matching ruthenium with dithiocarbamato ligands a potent chemotherapeutic weapon in oncology? Future Med. Chem. 2016, 8 (2), 211-226.

6. Skrott, Z.; Cvek, B., Diethyldithiocarbamate complex with copper: the mechanism of action in cancer cells. Mini-Reviews in Medicinal Chemistry 2012, 12 (12), 11841192.

7. $\quad$ Nagy, E. M.; Ronconi, L.; Nardon, C.; Fregona, D., Noble metal-dithiocarbamates precious allies in the fight against cancer. Mini-Reviews in Medicinal Chemistry 2012, 12 (12), 1216-1229.

8. Hogarth, G., Metal-dithiocarbamate complexes: chemistry and biological activity. Mini-Reviews in Medicinal Chemistry 2012, 12 (12), 1202-1215.

9. Buac, D.; Schmitt, S.; Ventro, G.; Kona, F. R.; Dou, Q. P., Dithiocarbamate-based coordination compounds as potent proteasome inhibitors in human cancer cells. MiniReviews in Medicinal Chemistry 2012, 12 (12), 1193-1201.

10. Milacic, V.; Dou, Q. P., The tumor proteasome as a novel target for gold(III) complexes: Implications for breast cancer therapy. Coord. Chem. Rev. 2009, 253 (11-12), 16491660.

11. Ronconi, L.; Fregona, D., The Midas touch in cancer chemotherapy: from platinum- to gold-dithiocarbamato complexes. Dalton Trans. 2009, (48), 10670-1068o.

12. Tiekink, E. R. T., Tin dithiocarbamates: applications and structures. Applied Organometallic Chemistry 2008, 22 (9), 533-550.

13. $\quad$ Milacic, V.; Fregona, D.; Dou, Q. P., Gold complexes as prospective metal-based anticancer drugs. Histology and Histopathology 2008, 23 (1), 101-108.

14. Nardon, C.; Fregona, D., Gold(III) Complexes in the Oncological Preclinical Arena: From Aminoderivatives to Peptidomimetics. Curr. Top. Med. Chem. 2016, 16 (3), 36o380.

15. Ronconi, L.; Marzano, C.; Zanello, P.; Corsini, M.; Miolo, G.; Macca, C.; Trevisan, A.; Fregona, D., Gold(III) dithiocarbamate derivatives for the treatment of cancer: Solution chemistry, DNA binding, and hemolytic properties. J. Med. Chem. 2006, 49 (5), 1648-1657. 
16. Milacic, V.; Fregona, D.; Dou, Q. P., Gold complexes as prospective metal-based anticancer drugs. Histol. Histopathol. 2008, 23, 101-108.

17. Boscutti, G.; Nardon, C.; Marchio, L.; Crisma, M.; Biondi, B.; Dalzoppo, D.; Dalla Via, L.; Formaggio, F.; Casini, A.; Fregona, D., Anticancer Gold(III) Peptidomimetics: From Synthesis to in vitro and ex vivo Biological Evaluations. ChemMedChem 2018, 13 (11), 1131-1145.

18. Milacic, V.; Chen, D.; Ronconi, L.; Landis-Piwowar, K. R.; Fregona, D.; Dou, Q. P., A novel anticancer gold(III) dithiocarbamate compound inhibits the activity of a purified $20 \mathrm{~S}$ proteasome and $26 \mathrm{~S}$ proteasome in human breast cancer cell cultures and xenografts. Cancer Res. 20o6, 66 (21), 1047810486.

19. McKeage, M. J.; Maharaj, L.; Berners-Price, S. J., Mechanisms of cytoxicity and antitumor activity og gold(I) phosphine complexes: the possible role of mitochondria. Coord. Chem. Rev. 2002, 232, 127-135.

20. Bindoli, A.; Rigobello, M. P.; Scutari, G.; Gabbiani, C.; Casini, A.; Messori, L., Thioredoxin reductase: A target for gold compounds acting as potential anticancer drugs. Coord. Chem. Rev. 2009, 253 (11-12), 1692-1707.

21. Huang, H. B.; Liao, Y. N.; Liu, N. N.; Hua, X. L.; Cai, J. Y.; Yang, C. S.; Long, H. D.; Zhao, C.; Chen, X.; Lan, X. Y.; Zang, D.; Wu, J. J.; Li, X. F.; Shi, X. P.; Wang, X. J.; Liu, J. B., Two clinical drugs deubiquitinase inhibitor auranofin and aldehyde dehydrogenase inhibitor disulfiram trigger synergistic anti-tumor effects in vitro and in vivo. Oncotarget 2016, 7 (3), 2796-2808.

22. Zhang, X.; Frezza, M.; Milacic, V.; Ronconi, L.; Fan, Y. H.; Bi, C. F.; Fregona, D.; Dou, Q. P., Inhibition of Tumor Proteasome Activity by Gold-Dithiocarbamato Complexes via Both Redox-Dependent and -Independent Processes. J. Cell. Biochem. 2010, 109 (1), 162.

23. Tomasello, M. F.; Nardon, C.; Lanza, V.; Di Natale, G.; Pettenuzzo, N.; Salmaso, S.; Milardi, D.; Caliceti, P.; Pappalardo, G.; Fregona, D., New comprehensive studies of a gold(III) Dithiocarbamate complex with. proven anticancer properties: Aqueous dissolution with cyclodextrins, pharmacokinetics and upstream inhibition of the ubiquitinproteasome pathway. Eur. J. Med. Chem. 2017, 138, 115-127.

24. Almond, J. B.; Cohen, G. M., The proteasome: a novel target for cancer chemotherapy. Leukemia 2002, 16 (4), 433-43.

25. An, B.; Goldfarb, R. H.; Siman, R.; Dou, Q. P., Novel dipeptidyl proteasome inhibitors overcome $\mathrm{Bcl}-2$ protective function and selectively accumulate the cyclin-dependent kinase inhibitor p27 and induce apoptosis in transformed, but not normal, human fibroblasts. Cell Death Differ. 1998, 5 (12), 1062-75.

26. Adams, J., Potential for proteasome inhibition in the treatment of cancer. Drug Discov. Today 2003, 8 (7), 307315 .

27. Atrian-Blasco, E.; Gascon, S.; Rodriguez-Yoldi, M. J.; Laguna, M.; Cerrada, E., Novel Gold(I) Thiolate Derivatives Synergistic with 5-Fluorouracil as Potential Selective Anticancer Agents in Colon Cancer. Inorg. Chem. 2017, 56 (14), 8562-8579.

28. Garcia-Moreno, E.; Tomas, A.; Atrian-Blasco, E.; Gascon, S.; Romanos, E.; Jesus Rodriguez-Yoldi, M.; Cerrada, E.; Laguna, M., In vitro and in vivo evaluation of organometallic gold(I) derivatives as anticancer agents. Dalton Trans. 2016, 45 (6), 2462-2475.

29. Atrián-Blasco, E.; Gascón, S.; Rodríguez-Yoldi, M. J.; Laguna, M.; Cerrada, E., Synthesis of Gold(I) Derivatives Bearing Alkylated 1,3,5-Triaza-7-phosphaadamantane as Selective Anticancer Metallodrugs. Eur. J. Inorg. Chem. 2016, 2791-2803.

30. García-Moreno, E.; Gascón, S.; Jalón, J. A. G. d.; Romanos, E.; Rodriguez-Yoldi, M. J.; Cerrada, E.; Laguna, M., In vivo anticancer activity, toxicology and histopathological studies of the thiolate gold(I) complex [Au(Spyrimidine)(PTA-CH2 $\mathrm{Ph})] \mathrm{Br}$. Anti-Cancer Agents Med. Chem. 2015, 15, 773-782.

31. Garcia-Moreno, E.; Gascon, S.; Atrian-Blasco, E.; Rodriguez-Yoldi, M. J.; Cerrada, E.; Laguna, M., Gold(I) complexes with alkylated PTA (1,3,5-triaza-7phosphaadamantane) phosphanes as anticancer metallodrugs. Eur. J. Med. Chem. 2014, 79, 164-172.

32. García-Moreno, E.; Cerrada, E.; Bolsa, M. J.; A. Luquin; Laguna, M., Water-Soluble Phosphanes Derived from 1,3,5-Triaza-7-phosphaadamantane and Their Reactivity towards Gold(I) Complexes. Eur. J. Inorg. Chem. 2013, 20202030.

33. Vergara, E.; Cerrada, E.; Clavel, C.; Casini, A.; Laguna, M., Thiolato gold(I) complexes containing watersoluble phosphane ligands: a characterization of their chemical and biological properties. Dalton Trans. 2011, 40 (41), 10927-10935.

34. Cerrada, E.; Fernandez, E. J.; Gimeno, M. C.; Laguna, A.; Laguna, M.; Terroba, R.; Villacampa, M. D., synthesis of dithiolate gold(iii) complexes by dithiolate transfer-reactions - $\quad x$-ray structure of $\mathrm{Au}\left(\mathrm{C} 6 F_{5}\right)\left(\mathrm{S}_{2} \mathrm{C}_{6} \mathrm{H}_{4}\right)(\mathrm{PPh}(3))$. J. Oganomet. Chem. 1995, 492 (1), 105-110.

35. Cerrada, E.; Fernandez, E. J.; Jones, P. G.; Laguna, A.; Laguna, M.; Terroba, R., Synthesis and reactivity of trinuclear gold(iii) dithiolate complexes - x-ray structure of $\mathrm{Au}\left(\mathrm{C} 6 \mathrm{~F}_{5}\right)\left(\mathrm{S}_{2} \mathrm{C}_{6} \mathrm{H}_{4}\right) \quad$ (3) AND

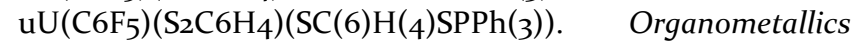
1995, 14 (12), 5537-5543.

36. Cerrada, E.; Laguna, M.; Sorolla, P. A., Gold complexes with 2-selenoxo-1,3-dithiole-4,5-dithiolato. Polyhedron 1998, 17 (2-3), 295-298.

37. Xanthopoulou, M. N.; Hadjikakou, S. K.; Hadjiliadis, N.; Kubicki, M.; Skoulika, S.; Bakas, T.; Baril, M.; Butler, I. S., Synthesis, structural characterization, and biological studies of six- and five-coordinate organotin(IV) complexes with the thioamides 2-mercaptobenzothiazole, 5-chloro-2mercaptobenzothiazole, and 2-mercaptobenzoxazole. Inorg. Chem. 2007, 46 (4), 1187-1195.

38. Brown, D. A.; Glass, W. K.; Burke, M. A., General use of ir spectral criteria in discussions of bonding and structure of metal dithiocarbamates. Spectrochim. Acta 1976, $32(1), 137-143$.

39. Durgaprasad, G.; Sathyanarayana, D. N.; Patel, C. C., Normal coordinate analysis of dialkyldithiocarbamate and its selenium analogue. Can. J. Chem. 1969, 47 (4), 631-+.

40. Bonati, F.; Ugo, R., Organotin(4) n,n-disubstituted dithiocarbamates. J. Organomet. Chem. 1967, 10 (2), 257-\&. 
41. Murray, H. H.; Garzon, G.; Raptis, R. G.; Mazany, A. M.; Porter, L. C.; Fackler, J. P., Sulfur-containing gold(III) chelates and their use in heterovalent dimer synthesis: crystal structures of $\mathrm{AuIII}\left[\mathrm{CH}_{2} \mathrm{P}(\mathrm{S}) \mathrm{Ph}_{2}\right]_{2} \mathrm{Br}$, [AuIII $\left.\left[\mathrm{S}_{2} \mathrm{P}(\mathrm{OH}) \mathrm{Ph}\right]_{2}\right] \mathrm{Cl}$, and $\mathrm{AuIII}\left[\mathrm{CH}_{2} \mathrm{P}(\mathrm{S}) \mathrm{Ph}_{2}\right]\left[\mathrm{S}_{2} \mathrm{CN}(\mathrm{Et})_{2}\right]$ 2. Inorg. Chem. 1988, 27 (5), 836-842.

42. Parish, R. V.; Howe, B. P.; Wright, J. P.; Mack, J.; Pritchard, R. G.; Buckley, R. G.; Elsome, A. M.; Fricker, S. P., Chemical and Biological Studies of Dichloro(2((dimethylamino)methyl)phenyl)gold(III). Inorg. Chem. 1996, 35 (6), 1659-1666.

43. Noordik, J. H., Cryst. Struct. Commun 1973, 2 (81$83)$.

44. Noordik, J. H.; Hummelink, T. W.; Van Der Linden, J. G. M., Structure and properties of n,n-di-nbutyldithiocarbamato-1, 2-dicyanoethene-1, 2-dithiolatogold(III). J. Coord. Chem. 1973, 2 (3), 185-191.

45. Vogler, A.; Kunkely, H., Photoreactivity of gold complexes. Coord. Chem. Rev. 2oo1, 219-221, 489-507.

46. Smith, D. A.; Van de Waterbeemd, H.; Walker, D. K., Pharmacokinetics and metabolism in drug design. WileyVCH, Ed. Weinheim, Germany, 2001.

47. Lakowicz, J. R., in 'Principles of fluorescence Spectroscopy'. Springer: Baltimore, Maryland, USA, 2006; p 277-330.

48. Zheng, C. Z.; Wang, H. P.; Xu, W.; Xu, C. Y.; Liang, J. G.; Han, H. Y., Study on the interaction between histidinecapped $\mathrm{Au}$ nanoclusters and bovine serum albumin with spectroscopic techniques. Spectrochim. Acta A 2014, 118, 897902.

49. Polet, H.; Steinhardt, J., Binding-induced alterations in ultraviolet abssorption of native serum albumin. Biochemistry 1968, 7 (4), 1348-1356.

50. Veeralakshmi, S.; Nehru, S.; Arunachalam, S.; Kumar, P.; Govindaraju, M., Study of single and double chain surfactant-cobalt(III) complexes and their hydrophobicity, micelle formation, interaction with serum albumins and antibacterial activities. Inorg. Chem. Front. 2014, 1 (5), 393404 .

51. Sanghvi, C. D.; Olsen, P. M.; Elix, C.; Peng, S.; Wang, D. S.; Chen, Z.; Shin, D. M.; Hardcastle, K. I.; MacBeth, C. E.; Eichler, J. F., Antitumor properties of fivecoordinate gold(III) complexes bearing substituted polypyridyl ligands. J. Inorg. Biochem. 2013, 128, 68-76.

52. Gouvea, L. R.; Garcia, L. S.; Lachter, D. R.; Nunes, P. R.; Pereira, F. D.; Silveira-Lacerda, E. P.; Louro, S. R. W.; Barbeira, P. J. S.; Teixeira, L. R., Atypical fluoroquinolone gold(III) chelates as potential anticancer agents: Relevance of DNA and protein interactions for their mechanism of action. Eur. J. Med. Chem. 2012, 55, 67-73.

53. Sambuy, Y.; De Angelis, I.; Ranaldi, G.; Scarino, M. L.; Stammati, A.; Zucco, F., The Caco-2 cell line as a model of the intestinal barrier: influence of cell and culture-related factors on Caco-2 cell functional characteristics. Cell Biol. Toxicol. 2005, 21 (1), 1-26.

54. Liévin-Le Moal, V.; Servin, A. L., Pathogenesis of Human Enterovirulent Bacteria: Lessons from Cultured, Fully Differentiated Human Colon Cancer Cell Lines. Microbiol. Mol. Biol. Rev. 2013, 77 (3), 380-439.
55. Berggren, M.; Gallegos, A.; Gasdaska, J. R.; Gasdaska, P. Y.; Warneke, J.; Powis, G., Thioredoxin and thioredoxin reductase gene expression in human tumors and cell lines, and the effects of serum stimulation and hypoxia. Anticancer Res. 1996, 16 (6B), 3459-3466.

56. Choi, J. H.; Kim, T. N.; Kim, S. Y.; Baek, S. H.; Kim, J. H.; Lee, S. R.; Kim, J. R., Overexpression of mitochondrial thioredoxin reductase and peroxiredoxin III in hepatocellular carcinomas. Anticancer Res. 2002, 22 (6A), 3331-3335.

57. Selvaraju, K.; Mazurkiewicz, M.; Wang, X.; Gullbo, J.; Linder, S.; D'Arcy, P., Inhibition of proteasome deubiquitinase activity: a strategy to overcome resistance to conventional proteasome inhibitors? Drug Resist. Update 2015, 21-22, 20-29.

58. Meister, S.; Schubert, U.; Neubert, K.; Herrmann, K.; Burger, R.; Gramatzki, M.; Hahn, S.; Schreiber, S.; Wilhelm, S.; Herrmann, M.; Jack, H. M.; Voll, R. E., Extensive immunoglobulin production sensitizes myeloma cells for proteasome inhibition. Cancer Res. 2007, 67 (4), 1783-1792.

59. McIlwain, D. R.; Berger, T.; Mak, T. W., Caspase Functions in Cell Death and Disease. Cold Spring Harb. Perspect. Biol. 2013, 5 (4), 28.

6o. Zeng, C. C.; Lai, S. H.; Yao, J. H.; Zhang, C.; Yin, H.; Li, W.; Han, B. J.; Liu, Y. J., The induction of apoptosis in HepG-2 cells by ruthenium(II) complexes through an intrinsic ROS-mediated mitochondrial dysfunction pathway. Eur. J. Med. Chem. 2016, 122, 118-126.

61. Ooi, K. K.; Yeo, C. I.; Ang, K. P.; Akim, A. M.; Cheah, Y. K.; Halim, S. N.; Seng, H. L.; Tiekink, E. R., Phosphanegold(I) thiolates, $\mathrm{Ph} 3 \mathrm{PAu}\left[\mathrm{SC}(\mathrm{OR})=\mathrm{NC} 6 \mathrm{H}{ }_{4} \mathrm{Me}-4\right]$ for $\mathrm{R}=\mathrm{Me}$, Et and iPr, induce apoptosis, cell cycle arrest and inhibit cell invasion of HT-29 colon cancer cells through modulation of the nuclear factor-kappaB activation pathway and ubiquitination. J. Biol. Inorg. Chem. 2015, 20 (5), 855-73.

62. Gottlieb, E.; Armour, S. M.; Harris, M. H.; Thompson, C. B., Mitochondrial membrane potential regulates matrix configuration and cytochrome c release during apoptosis. Cell Death Differ. 2003, 10 (6), 709-17.

63. Elmore, S., Apoptosis: a review of programmed cell death. Toxicol. Pathol. 2007, 35 (4), 495-516.

64. Che, C. M.; Sun, R. W. Y.; Yu, W. Y.; Ko, C. B.; Zhu, N. Y.; Sun, H. Z., Gold(III) porphyrins as a new class of anticancer drugs: cytotoxicity, DNA binding and induction of apoptosis in human cervix epitheloid cancer cells. Chem. Commun. 2003, (14), 1718-1719.

65. Zhang, Z.; Wang, H. Y.; Yan, M. C.; Wang, H. N.; Zhang, C. Y., Novel copper complexes as potential proteasome inhibitors for cancer treatment. Mol. Med. Reports 2017, 15 (1), 3-11.

66. Rigobello, M. P.; Messori, L.; Marcon, G.; Agostina Cinellu, M.; Bragadin, M.; Folda, A.; Scutari, G.; Bindoli, A., Gold complexes inhibit mitochondrial thioredoxin reductase: consequences on mitochondrial functions. J. Inorg. Biochem. 2004, 98 (10), 1634-41.

67. Arner, E. S. J.; Holmgren, A., Physiological functions of thioredoxin and thioredoxin reductase. Eur. J. Biochem. 2000, 267 (20), 6102-6109.

68. Vergara, E.; Casini, A.; Sorrentino, F.; Zava, O.; Cerrada, E.; Rigobello, M. P.; Bindoli, A.; Laguna, M.; Dyson, P. J., Anticancer Therapeutics That Target Selenoenzymes: Synthesis, Characterization, in vitro Cytotoxicity, and 
Thioredoxin Reductase Inhibition of a Series of Gold(I) Complexes Containing Hydrophilic Phosphine Ligands. ChemMedChem 2010, 5 (1), 96-102.

69. Nordberg, J.; Arner, E. S., Reactive oxygen species, antioxidants, and the mammalian thioredoxin system. Free Radic. Biol. Med. 2001, 31 (11), 1287-312.

70. Zhang, J. M.; Li, X. M.; Han, X.; Liu, R. J.; Fang, J. G., Targeting the Thioredoxin System for Cancer Therapy. Trends Pharmacol. Sci. 2017, 38 (9), 794-808.

71. Nguyen, P.; Awwad, R. T.; Smart, D. D. K.; Spitz, D. R.; Gius, D., Thioredoxin reductase as a novel molecular target for cancer therapy. Cancer Lett. 2oo6, 236 (2), 164-174. 72. Shaik, N.; Martinez, A.; Augustin, I.; Giovinazzo, H.; Varela-Ramirez, A.; Sanau, M.; Aguilera, R. J.; Contel, M., Synthesis of apoptosis-inducing iminophosphorane organogold(III) complexes and study of their interactions with biomolecular targets. Inorg. Chem. 2009, 48 (4), 15771587 .

73. Cattaruzza, L.; Fregona, D.; Mongiat, M.; Ronconi, L.; Fassina, A.; Colombatti, A.; Aldinucci, D., Antitumor activity of gold( III)-dithiocarbamato derivatives on prostate cancer cells and xenografts. Int. J. Cancer 2011, 128 (1), 206215 .

74. Saggioro, D.; Rigobello, M. P.; Paloschi, L.; Folda, A.; Moggach, S. A.; Parsons, S.; Ronconi, L.; Fregona, D.; Bindoli, A., Gold(III) - Dithiocarbamato complexes induce cancer cell death triggered by thioredoxin redox system inhibition and activation of ERK pathway. Chem. Biol. 2007, 14 (10), 1128-1139.

75. Fritz-Wolf, K.; Urig, S.; Becker, K., The structure of human thioredoxin reductase 1 provides insights into Cterminal rearrangements during catalysis. J. Mol. Biol. 20o7, 370 (1), 116-127.

76. Cheng, Q.; Sandalova, T.; Lindqvist, Y.; Arner, E. S. J., Crystal Structure and Catalysis of the Selenoprotein Thioredoxin Reductase 1. J. Biol. Chem. 2oo9, 284 (6), 39984008.

77. Lu, J.; Holmgren, A., The thioredoxin antioxidant system. Free Radic. Biol. Med. 2014, 66, 75-87.

78. Citta, A.; Schuh, E.; Mohr, F.; Folda, A.; Massimino, M. L.; Bindoli, A.; Casini, A.; Rigobello, M. P., Fluorescent silver(I) and gold(I)-N-heterocyclic carbene complexes with cytotoxic properties: mechanistic insights. Metallomics 2013, 5 (8), 1006-1015.

79. Gabbiani, C.; Mastrobuoni, G.; Sorrentino, F.; Dani, B.; Rigobello, M. P.; Bindoli, A.; Cinellu, M. A.; Pieraccini, G.; Messori, L.; Casini, A., Thioredoxin reductase, an emerging target for anticancer metallodrugs. Enzyme inhibition by cytotoxic gold(III) compounds studied with combined mass spectrometry and biochemical assays. Med. Chem. Commun 2011, 2 (1), 50-54.

8o. Ronconi, L.; Aldinucci, D.; Dou, Q. P.; Fregona, D., Latest Insights into the Anticancer Activity of Gold(III)Dithiocarbamato Complexes. Anti-Cancer Agent Med. Chem. 2010, 10 (4), 283-292.

81. Hershko, A.; Ciechanover, A., The ubiquitin system. Annu. Rev. Biochem. 1998, 67, 425-79.

82. Chen, L.; Madura, K., Increased proteasome activity, ubiquitin-conjugating enzymes, and eEF1A translation factor detected in breast cancer tissue. Cancer Res. 2005, 65 (13), 5599-606.
83. Arlt, A.; Bauer, I.; Schafmayer, C.; Tepel, J.; Muerkoster, S. S.; Brosch, M.; Roder, C.; Kalthoff, H.; Hampe, J.; Moyer, M. P.; Folsch, U. R.; Schafer, H., Increased proteasome subunit protein expression and proteasome activity in colon cancer relate to an enhanced activation of nuclear factor E2-related factor 2 (Nrf2). Oncogene 2009, 28 (45), 3983-96.

84. Milacic, V.; Banerjee, S.; Landis-Piwowar, K. R.; Sarkar, F. H.; Majumdar, A. P.; Dou, Q. P., Curcumin inhibits the proteasome activity in human colon cancer cells in vitro and in vivo. Cancer Res. 20o8, 68 (18), 7283-92.

85. Orlowski, R. Z.; Kuhn, D. J., Proteasome inhibitors in cancer therapy: Lessons from the first decade. Clin. Cancer Res. 2008, 14 (6), 1649-1657.

86. Vermeulen, K.; Van Bockstaele, D. R.; Berneman, Z. $\mathrm{N}$., The cell cycle: a review of regulation, deregulation and therapeutic targets in cancer. Cell Prolif. 2003, 36 (3), 131-49.

87. Adams, J., The proteasome: structure, function, and role in the cell. Cancer Treat. Rev. 2003, 29 Suppl 1, 3-9.

88. Chu, I. M.; Hengst, L.; Slingerland, J. M., The Cdk inhibitor p27 in human cancer: prognostic potential and relevance to anticancer therapy. Nat. Rev. Cancer 2oo8, 8 (4), 253-67.

89. Pagano, M.; Tam, S. W.; Theodoras, A. M.; BeerRomero, P.; Del Sal, G.; Chau, V.; Yew, P. R.; Draetta, G. F.; Rolfe, M., Role of the ubiquitin-proteasome pathway in regulating abundance of the cyclin-dependent kinase inhibitor p27. Science 1995, 269 (5224), 682-5.

90. Wander, S. A.; Zhao, D.; Slingerland, J. M., p27: a barometer of signaling deregulation and potential predictor of response to targeted therapies. Clin. Cancer Res. 2011, 17 (1), 12-8.

91. Rastogi, N.; Mishra, D. P., Therapeutic targeting of cancer cell cycle using proteasome inhibitors. Cell Div. 7 (1), 26.

92. Chen, Z. J., Ubiquitin signalling in the NF-kappaB pathway. Nat. Cell Biol. 2005, 7 (8), 758-65.

93. Ronconi, L.; Giovagnini, L.; Marzano, C.; Bettio, F.; Graziani, R.; Pilloni, G.; Fregona, D., Gold dithiocarbamate derivatives as potential antineoplastic agents: Design, spectroscopic properties, and in vitro antitumor activity. Inorg. Chem. 2005, 44, 1867-1881.

94. M. N. Xanthopoulou; S. K. Hadjikakou; N. Hadjiliadis; M. Kubicki; S. Skoulika; T. Bakas; M. Baril; Butler, I. S., Inorg. Chem. 2007, (46), 1187-1195.

95. E. Martin; C. Spendley; A. J. Mountford; S. J. Coles; P. N. Horton; D. L. Hughes; M. B. Hursthouse; S. J. Lancaster, Organometallics 20o8, 27, 1436-1446.

96. CysAlisPro Multiscan absorption correction with SCALE3 ABSPACK scaling algorithm, 1.171.35.11; Agilent Technologies.

97. Sheldrick, G. M., A short history of SHELX. Acta Crystallogr. A 2008, 64 (Pt 1), 112-22.

98. Mote, U. S.; Bhattar, S. L.; Patil, S. R.; Kolekar, G. B., Interaction between felodipine and bovine serum albumin: fluorescence quenching study. Luminescence 2010, 25 (1), 1-8. 99. Wang, C. X.; Yan, F. F.; Zhang, Y. X.; Ye, L., Spectroscopic investigation of the interaction between rifabutin and bovine serum albumin. J. Photochem. Photobio. A 2007, 192 (1), 23-28. 
100. van Meerloo, J.; Kaspers, G. J.; Cloos, J., Cell sensitivity assays: the MTT assay. Methods Mol. Biol. 2011, 731, 237-45. 
Insert Table of Contents Graphic and Synopsis

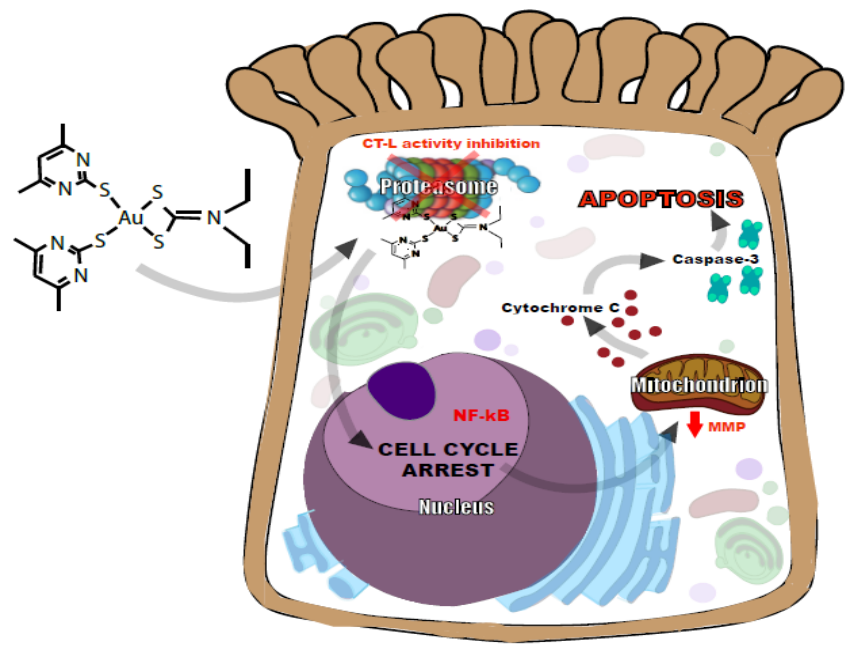

Synopsis

A family of mixed gold(III) derivatives with dithiocarbamate and thiolate ligands have been described as possible anticancer agents against colon cancer cell lines. The complexes are able to reduce the cell viability and proliferation by apoptotic pathway through inhibition of proteasome. 